\title{
A critical review of sedimentation trap technique ${ }^{1}$ )
}

\author{
By J. Bloesch* and N.M. Burns** \\ * Eidg. Anstalt für Wasserversorgung, Abwasserreinigung und Gewässerschutz (EAWAG), \\ Dübendorf, Switzerland \\ ** Canada Centre for Inland Waters, Burlington, Ontario, Canada
}

Manuscript received on 19 June 1979

\begin{abstract}
The published literature on the use of sediment traps has been reviewed and used to validate the conclusions of a theoretical analysis of the physical factors affecting the trapping of particles. Both practical and theoretical considerations lead us to recommend that the 'best' sediment trap for use in limnology is a simple cylinder with a diameter of from 5 to $20 \mathrm{~cm}$ and aspect ratio (ratio of length to diameter) of greater than 5 for small lakes and greater than 10 for more turbulent water bodies. We also demonstrate the need to know the approximate particle Reynolds number of particles being collected by sediment traps. A number of considerations lead us to advise against the use of collars. lattices, baffes. lids or reference chambers. Recommendations are made on minimizing the unresolved problem of mineralization of organic material and on optimum length of exposure times, mooring systems, trap holding frames and sample handling.
\end{abstract}

\section{CON'TENTS}

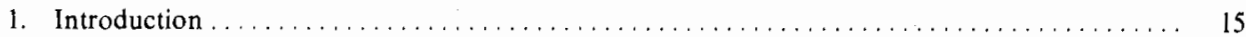

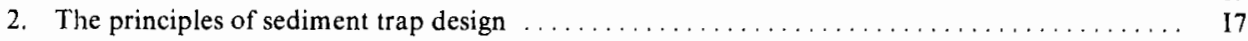

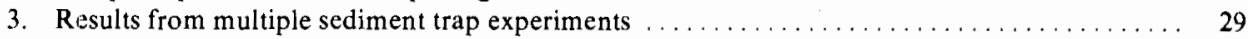

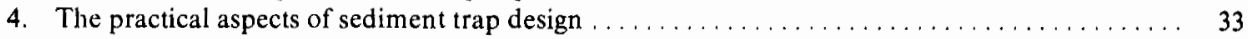

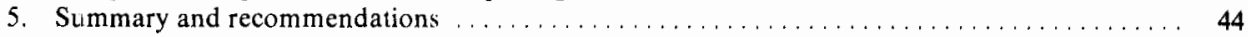

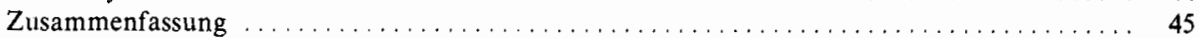

Résumé.............................................. 46

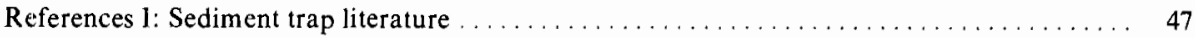

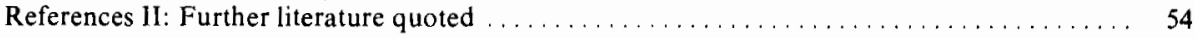

\section{Introduction}

The first use of a sediment collector was reported by Albert Heim [57] at the turn of this century. Only in the 1950's, however, did sedimentation traps become a more popular tool in the study of settling processes in lakes and oceans. There has been a tremendous increase in the number of investigations about sedimentation over the

1) Revised form of paper was presented by J. Bloesch at the UNESCO-Workshop 'On the assessment of particulate matter contamination in rivers and lakes' held in Budapest, 13-17 November 1978. 
past three decades and more than 150 papers dealing with traps have been written (see references I). Progress in sediment trap technique has largely been limited to introducing new designs on the basis of intuition instead of investigating the in situ physics of catching and retaining particles. Until recently, the geometrical forms of traps (fig. 1) were chosen in an arbitrary manncr without considering the physics of the problem. The large number of different traps is confusing since only a few authors tested their designs by comparing the catches of different types of traps [21, $74,84,117,174]$. Further, only a limited number of systematic studies of trap efficiency has been made $[36-38,51,89,115,156,169]$.

To the present, physical dynamic flow-patterns around traps and the real effects of trap walls on particle settling have not been fully quantified. Besides the geometrical form, unsettled debates include closing systems (lids), mooring systems and other accessories, as well as correction for wall-attached growth ('Aufwuchs').

The controversial opinions of experts are even more confusing than the large number of trap designs. Golterman [44] states: "The traps so far used, increased the sedimentation rate by decreasing the turbulence of the water in their vicinity" (p.526). Hargrave and McIntyre [52] agreed with this by stating: "It is apparent that in all areas except those with low horizontal velocity, a trap of a cylindrical shape considerably overestimates the settling rate" (p.299). Gardner [38], on the contrary, concludes from his trap efficiency experiments and field calibrations that "cylinders

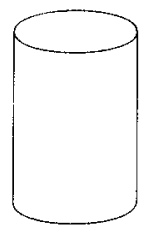

(1) Cylinders

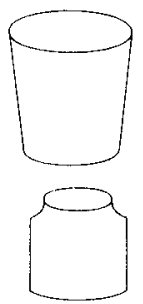

(4) Jars

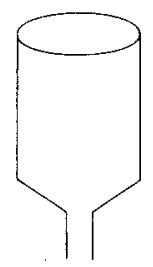

(2) Cylinders with funnel bases

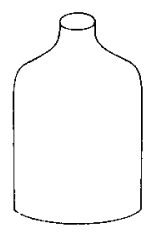

(5) Bottles and similar vessels

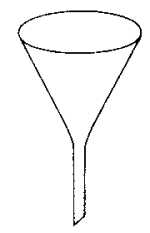

(3) Funnels

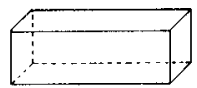

(6) Containers or pans

(7) Some unknown configurations

Figure 1. Different geometrical forms of sedimentation traps. The cylinder-shaped traps. wide-mouthed jars and funnels are the most common (see table 4).

Abb. 1. Verschiedene geometrische Formen von Sedimentfallen. Am häufigsten im Gebrauch sind Zylinder (1), weithalsige Gefässe (4) und Trichter (3) (siehe Tab.4). 
appear to yield accurate measurements of vertical flux if their aspect ratios are between 2 and 3. There will be differences even over this range, and the best choice may depend on the velocity regime, with taller traps being used at higher velocities to prevent resuspension" (summary, part 3 ).

In regard to mineralization in traps, limited exposure time or preservatives are thought to prevent excess decomposition of organic material. Golterman [44] writes on this problem: "Living material caught in the trap may die and may be digested by bacteria. (...) Even dead material may undergo such alterations. If bactericides and the like are added to the trap, they may kill off living algae, and increase the mineralization." As an example, he refers to Kleerekoper [86], who found a high percentage of mineralization in his collected sinking material, and comments: "It is not unlikely that this (i.e. the quite high phosphate content in the collected material) is due to bacterial growth in the sedimentation trap. (...) Analysis of total phosphates from these traps are therefore unreliable" (p.526). Kajak (in Edmondson and Winberg [28]), on the other hand, has an opposing opinion and writes that "according to our materials, when different times of exposure were used and to some containers preservatives were added (formalin, chloroform), there was no substantial influence of the containers' time of exposure on their content of organic matter" (p.23).

Despite criticism, users of traps are convinced in general that traps are the best tool to measure downward settling fluxes and the instrumental errors are within reasonable limits. We only know of one paper where the author fully rejects his trap-results due to "horizontal movement and focussing of sediment or for some other reason" ([26], p. 193). However, the influence of horizontal currents has been recognized by numerous authors, and the effects of sediment focussing (funnel or 'Trichter' effect) and resuspension of bottom deposits are well known. These interferences belong to the interpretation of obtained data and are not discussed further, because we are only analyzing sediment traps as instruments which measure the settling flux of particles from the water surrounding the traps. Sediment traps are simple instruments and care must be taken that results from them are not overinterpreted in describing limnological or oceanographic processes.

The purpose of this paper is to point out the basic physics of settling mechanisms around and within a trap, and resolve contradictions as described above. Further, using these concepts together with recent experiments about trap efficiency, we wish to recommend the 'best' trap. We hope that a certain degree of standardization of traps can follow which will facilitate comparison of different results. We also wish to show the continuing and inherent weaknesses of the sediment trap technique and to suggest further investigations needed to quantify and remove these sources of error.

\section{The principles of sediment trap design}

The waters of lakes and oceans, especially the surface waters, are sometimes calm, but are often turbulent. Thus, sediment traps used in lakes and oceans must be able to collect material at the correct flux rate in both calm and moving water. This requires that we determine the important processes affecting settling from calm and turbulent water and then decide on the design principles which must be adhered to. 
These processes appear to be: a) the effect of turbulence on the settling velocity of particles; b) the effect of vessel shape on collection efficiency in calm and flowing water; c) the interaction of vessel shape and turbulence on the mean concentrations of particles suspended within a sediment trap; d) the effect of particle concentration within a trap on the sediment collection efficiency of a trap.

Turbulence can affect the flux of particles through the water column in a number of ways. Turbulence causes resuspension of particles off the bottom of the lake or a layer in the thermocline and then redistributes these particles through the water column, usually causing a net upward transport of particles. Although turbulence can affect the settling velocity of particles under certain circumstances, its effect on mixing particles from zones of high concentration (e.g. near the bottom) to lower concentration is generally the more pronounced effect. This process can lead to the misconception that turbulence considerably reduces the settling velocity of particles because of the net upward transport of particles. This is not the case; particles settle downward through the surrounding water whether it is calm or turbulent. Turbulence basically affects the distribution of particles in the water column.

Turbulence, then, can have two effects on the suspended particles; the major effect being the redistribution of particles in the water column with the minor effect being the alteration of the velocity at which particles actually settle through the surrounding fluid. In other words, even where no effective redistribution of particles occurs, turbulence may affect the settling flux of particles as in a water mass where there are no concentration gradients present and where no resuspension of particles is possible (a well mixed epilimnion would be an example of such a water mass). The vertical redistribution of particles will not be considered here but the effect of turbulence on the actual settling velocity of particles does concern us.

In regard to the effect of turbulence on settling, Jobson and Sayre [189] stated: "It is often assumed that the mean value of the particle fall velocity is unaffected by turbulent fluctuations of the fluid, but no convincing criteria have been presented indicating the limits of this assumption." They then reported the results of their investigation on the effect of turbulence and sheared flow on the settling velocity of small particles. These particles were small glass beads and sand grains with settling velocities of 1.09 and $6.30 \mathrm{~cm} \mathrm{sec}^{-1}$, respectively. Their data indicate that the increase in settling velocity caused by turbulence was of the order of $5 \%$. In another study of the same problem, Murray [194] found that particles with calm water settling velocities of between 1.0 and $4.0 \mathrm{~cm} \mathrm{sec}{ }^{-1}$ settled slower under turbulent conditions. In fact, turbulence will have no effect on small organic particles $(<500 \mu \mathrm{m})$ settling in water because their particle Reynolds numbers, $\mathrm{Re}$, are usually less than $0.5 .\left(R e=V_{s} \cdot d / v\right.$ where $V_{s}$ is the particle settling velocity, $d$ is the diameter of the particle and $v$ is the kinematic viscosity.) Hutchinson [187] and Smith [200] have pointed out that Stokes' law holds for particles having $\operatorname{Re}<0.5$. This means that the flow around these particles when moving through a fluid is laminar and that the drag force, $D_{f}$, on a particle is proportional to its velocity of movement through the fluid. Thus, if $\operatorname{Re}<0.5$ and a particle is in a mass of fluid which is undergoing turbulent motion, then

$$
\mathrm{D}_{\mathrm{f}}=3 \pi v \mathrm{~d}\left(\mathrm{~V}_{\mathrm{f}}-\mathrm{V}_{\mathrm{p}}\right)=3 \pi v \mathrm{~d} \mathrm{~V}_{\mathrm{s}}
$$


where $v=$ viscosity; $\mathbf{d}=$ diameter of particles; $\mathrm{V}_{\mathrm{f}}=$ velocity of fluid; $\mathrm{V}_{\mathrm{P}}=$ velocity of particle.

This linear relationship between drag force and relative particle velocity will result in the sum of the accelerations of the particle caused by the accelerations of the surrounding fluid to be equal to zero, if the turbulent velocity fluctuations in the surrounding fluid are also equal to zero.

This is not the case with larger particles having Reynolds numbers $>80$. The drag force of the water on these particles is given by Smith [200]

$$
\mathrm{D}_{\mathrm{f}}=\frac{\mathrm{C}_{\mathrm{d}} \mathrm{A}_{\mathrm{m}} \rho\left(\mathrm{V}_{\mathrm{f}}-\mathrm{V}_{\mathrm{p}}\right)^{2}}{2}
$$

where $\mathrm{C}_{\mathrm{d}}=\mathrm{drag}$ coefficient; $\mathrm{A}_{\mathrm{m}}=$ cross-sectional area of particle; $\rho=$ density of particle.

The relationship shown in equation (2) would mean that the sum of the accelerations experienced by a larger particle in a turbulent fluid may not equal zero even while the sum of the velocity changes experienced by the turbulent fluid were equal to zero. In other words, particles in this Reynolds number range would be affected by turbulence.

In the intermediate particle Reynolds number range 0.5 to 80 [200] or 1 to 100 [182], the relationship between the drag force and the relative particle velocity is variable

$$
\mathrm{D}_{\mathrm{f}}=\frac{\mathrm{C}_{\mathrm{d}} \mathrm{A}_{\mathrm{m}} \rho\left(\mathrm{V}_{\mathrm{f}}-\mathrm{V}_{\mathrm{p}}\right)^{\mathrm{x}}}{2}
$$

where $1<x<2$.

The effect of turbulence on particles in this range would increase with the particle Reynolds number and with the turbulence. This is illustrated by the results of Jobson and Sayre [189] who settled particles with Reynolds numbers of 1 and 24, respectively, in mildly turbulent water and found little effect of the turbulence on the particle settling velocity. Murray [194] measured the settling velocity of particles with $R$ e varying from 20 to 80 in water with conditions ranging from mildly turbulent to extremely turbulent. He found that the settling velocity was decreased significantly with increasing particle Reynolds number and increasing turbulence.

Thus, if the particles under study are settling through turbulent water, it is important to have some knowledge of the range of Re values of these particles. This topic is dealt with in some detail by Hutchinson [187]. An example of a particle which is just within the Stokes' settling range would be an organic particle of about $250 \mu \mathrm{m}$ equivalent spherical diameter which settles at approximately $200 \mathrm{~m} \mathrm{day}^{-1}$. This would correspond roughly to the large fecal pellets found in oceans [199]. However, the vast majority of organic particles under investigation in fresh waters would be smaller than this and settle at much lower velocities [181]. For this reason, we will assume that turbulence does not affect the settling velocity of the smaller particles $(<250 \mu \mathrm{m})$ in lakes. The following analysis is based on this assumption. In cases where this assumption is not valid, a correction can be made and this point is discussed below. 
Table 1. Vertical sinking velocities of particles vs. horizontal movements in air and water (according to Gardner [36]).

Tabelle 1. Vergleich der vertikalen Sinkgeschwindigkeit verschiedener Partikel mit horizontalen Strömungen in Luft und Wasser (nach Gardner [36]).

\begin{tabular}{|c|c|c|c|c|}
\hline Particle & Diameter & $\begin{array}{l}\text { Sinking } \\
\text { velocity }\end{array}$ & $\begin{array}{l}\text { Wind speed } \\
\text { or horizontal } \\
\text { current velocity }\end{array}$ & $\begin{array}{r}\text { Proportional } \\
\text { difference in } \\
\text { velocity }\end{array}$ \\
\hline Rain drops & $\left.0.05-5 \mathrm{~mm}^{\mathrm{l}}\right)$ & $\left.2.3-9.3 \mathrm{~m} / \mathrm{sec}^{1}\right)$ & $\left.<10 \mathrm{~m} / \mathrm{sec}^{4}\right)$ & $<10$ \\
\hline Snow flakes & - & $0.5 \mathrm{~m} / \mathrm{sec}^{1}$ ) & & \\
\hline $\begin{array}{l}\text { Sedimenting } \\
\text { particles } \\
\text { Sedimenting }\end{array}$ & $1 \mu \mathrm{m}$ & $\left.10^{-4} \mathrm{~cm} / \mathrm{sec}^{2}\right)$ & $\left.<200 \mathrm{~cm} / \mathrm{sec}^{4_{i 3}}\right)$ & \\
\hline $\begin{array}{l}\text { particles } \\
\text { Fecal pellets }\end{array}$ & $40 \mu \mathrm{m}$ & $\begin{array}{l}\left.10^{-1} \mathrm{~cm} / \mathrm{sec}^{2}\right) \\
\left.0.04-1.0 \mathrm{~cm} / \mathrm{sec}^{3}\right)\end{array}$ & $\begin{array}{l}\left.<20 \mathrm{~cm} / \mathrm{sec}^{4 b}\right) \\
\left.<30 \mathrm{~cm} / \mathrm{sec}^{5 a}\right) \\
\left.<5 \mathrm{~cm} / \sec ^{5 b}\right)\end{array}$ & $10-10^{6}$ \\
\hline
\end{tabular}

1) After Kurtyka [193].

2) After Stokes' Law $\left(\xi<2 \mathrm{~g} / \mathrm{cm}^{3}\right)$.

3) After Smayda [198]. Fowler and Small [183].

4) Assumption of Gardner [36], 4a) = estuaries and surface of oceans, 4b) $=$ deep layers of oceans.

5) After Hutchinson [188], 5a) = surface of lakes, 5b) = deep hypolimnion of lakes.

We also wish to point out that the settling pathways of small particles in water must not be compared with those of particles in the air, such as rain drops or snow flakes. Table 1 shows that the vertical sinking velocity of settling particles is 1 to 6 orders of magnitude less than horizontal water currents, whereas in air, the settling velocities of snow and rain are almost of the same order of magnitude as horizontal air currents. Thus, we must dismiss the common concept of a steady 'rain' of detritus or phytoplankton cells sinking downward. In water, the particles always have a small constant component of downward movement but do not appear to be sinking vertically or even at a certain angle, but appear to be carried passively in turbulent eddies. It is by this means that they are swept into sediment traps [36]. We have to imagine that the small particles settle very slowly downwards through the water mass which is swirling them around and that only when they are swept into a trap, is the horizontal component of their movement removed. The small vertical component remains and causes the particles to sink to the bottom of the trap.

The effect of water flowing around cylindrical traps has recently been investigated $[36,51]$ in tanks and flumes, and also in oceans and lakes. Experiments using dye $[36,146]$ or oil droplets [89] have made the turbulence patterns visible. Some of the water flowing past the traps enters them and causes turbulence in the cylinders. It was found that if the traps have relatively low aspect ratios (aspect ratio $=$ height/ diameter) some of the turbulence can reach the bottom of the traps and resuspend part of the material settled on the bottom. Lau [89] found a direct relationship between flow around a cylinder (as defined by the flow Reynolds number) and the aspect ratio of the cylinder which was required to prevent turbulence reaching the bottom of the cylinder. He and Hargrave and Burns [51] found that cylinders with an aspect ratio of greater than 10 would maintain a layer of calm water above the 
bottom of the trap in the normal flow conditions encountered in lakes and the open ocean, i.e., a current of about $30 \mathrm{~cm} \mathrm{sec}^{-1}$ flowing around a $10 \mathrm{~cm}$ diameter trap.

The consequences of the settling velocity of particles being independent of the ambient turbulence are best illustrated by a few examples. In figure $2 \mathrm{a}$, a cylinder with an aspect ratio of 10 is sitting in calm water having no concentration gradients. The settling flux of particles will be the same at all levels around the trap and within the trap, namely

$$
\mathrm{F}=\mathrm{V}_{0} \mathrm{C}_{0} \quad\left(\mathrm{ML}^{-2} \mathrm{~T}^{-1}\right)
$$

where $F=$ settling flux $\left(\mathrm{ML}^{-2} \mathrm{~T}^{-1}\right) ; \mathrm{V}_{0}=$ mean particle settling velocity in water outside of the trap $\left(\mathrm{LT}^{-1}\right) ; \mathrm{C}_{0}=$ mean particle concentration in water outside of the $\operatorname{trap}\left(\mathrm{ML}^{-3}\right)$.

Since the water is calm there will be no differences in settling velocity and concentration between the water outside or inside the trap. The total flux into the trap would be

$$
\mathrm{F}_{1}=\mathrm{A}_{0} \mathrm{~F} \quad\left(\mathrm{MT}^{-1}\right)
$$

where $A_{0}=$ area of opening of the $\operatorname{trap}\left(L^{2}\right)$.

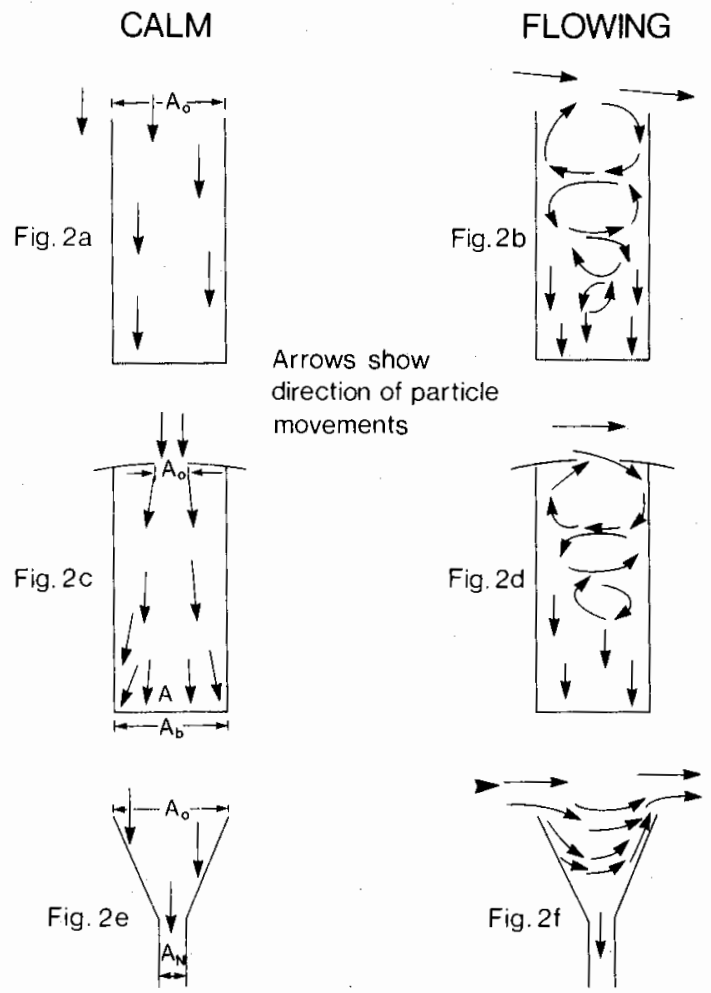

Figure 2. Schematic diagram showing probable paths of some particles.

Abb.2. Schematische Darstellung von möglichen Wegen (Pfeilrichtungen) sedimentierender Partikel. 
Since the trap is cylindrical, the flux onto the bottom of the trap would be the same as $F_{t}$.

Figure $2 \mathrm{~b}$ depicts the same trap as in figure $2 \mathrm{a}$ in flowing water having no concentration gradients but having eddies within the trap. In their experiments, Gardner [36] and Lau [89] found an upward deflection of the flow at the top of the streamward wall which created an undefined number of vortices carrying into the trap as well as over the trap beyond the lee wall (fig. 2b, 2 d, 2 f). Each eddy induced another downwards in the trap, with each eddy being opposite in direction and decreasing in magnitude from the top to near the bottom (fig. 2 b, $2 \mathrm{~d}$ ).

Since turbulence does not affect the settling velocity of particles, the total settling flux into the trap in flowing water will also be $F_{t}$. At the same time, particles will be carried into the trap by flowing water entering the trap. The number of particles entering the trap by this means, $\mathrm{P}$, would be

$$
\mathrm{P}=\mathrm{Q}_{\mathrm{e}} \mathrm{C}_{0} \quad\left(\mathrm{MT}^{-1}\right)
$$

where $Q_{e}$ is the volume of water entering the trap per sec. In this trap, with a high aspect ratio (fig. 2 b), the turbulence will decrease from the top downwards and there will be a zone of calm water at the bottom. Because of this, there will be no resuspension of the particles already settled on the bottom of the trap. Since the number of particles entering the trap must be the same as those leaving the trap by the different means, the following equation can be written
$\mathrm{A}_{0} \mathrm{~V}_{0} \mathrm{C}_{0}+\mathrm{Q}_{\mathrm{e}} \mathrm{C}_{0}=\mathrm{A}_{0} \mathrm{~V}_{\mathrm{t}} \mathrm{C}_{\mathrm{t}}$
$+$
$\mathrm{Q}_{1} \mathrm{C}_{\mathrm{t}}$
$\left(\mathrm{MT}^{-1}\right)$
particles
entering trap
particles settling
particles
out on bottom of trap
leaving trap

where $V_{t}=$ settling velocity of particles onto the bottom of the $\operatorname{trap}\left(\mathrm{LT}^{-1}\right) ; \mathrm{C}_{1}=$ mean concentration of particles in water inside the trap $\left(\mathrm{ML}^{-3}\right)$; and $\mathrm{Q}_{1}=$ volume of water leaving the trap per sec $\left(\mathrm{L}^{3} \mathrm{~T}^{-1}\right)$.

Under the assumptions and conditions stated, $\mathrm{V}_{0}=\mathrm{V}_{1}$. The water under these conditions would be incompressible and thus $\mathrm{Q}_{\mathrm{e}}=\mathrm{Q}_{1}=\mathrm{Q}$. Also, there is no resuspension of settled material. Further, since there is no destruction or creation of particles, equation (7) must balance, and this is only possible if $C_{0}=C_{t}$, i.e., the concentration of particles inside the trap must be the same as that outside the trap. From this it also follows that

$$
A_{0} V_{t} C_{t}=A_{0} V_{0} C_{0}=F_{t} \quad\left(M^{-1}\right)
$$

which means that the flux of particles settling to the bottom of the cylinder in flowing water is equal to the settling flux in the same water when it is calm.

It is worth comparing the magnitude of the terms $A_{0} V_{0} C_{0}$ or $A_{0} V_{t} C_{t}$ with $Q_{e} C_{0}$. If we have a trap with $A_{0}=50 \mathrm{~cm}^{2}$ in water moving at $10 \mathrm{~cm} \mathrm{sec}^{-1}$ average velocity, it is possible that the water welling down into the trap may do so at an average speed of $5 \mathrm{~cm} \mathrm{sec}^{-1}$ over an area of $10 \mathrm{~cm}^{2}$, i.e., $\mathrm{Q}_{\mathrm{e}}=50 \mathrm{~cm}^{3} \mathrm{sec}^{-1}$. If $\mathrm{C}_{0}=500 \mu \mathrm{g}$ particulate 
organic carbon (POC) $l^{-1}$, then $\mathrm{Q}_{e} \mathrm{C}_{0}=25 \mu \mathrm{g} \mathrm{sec}{ }^{-1} \mathrm{POC}$. If $\mathrm{V}_{0}=1.0 \times 10^{-3} \mathrm{~cm} \mathrm{sec}^{-1}$ $\left(0.86 \mathrm{~m}_{\text {day }}-1\right)$, then $\mathrm{A}_{0} \mathrm{~V}_{0} \mathrm{C}_{0}=25 \times 10^{-3} \mu \mathrm{g} \mathrm{sec}^{-1} \mathrm{POC}$. This means that the flux of particles passing through the trap would be of the order of 1,000 times greater than the flux of particles settling into the trap or onto the bottom of the trap. This flux of particles through the opening of the trap does not affect the flux of particles onto the bottom of the trap. A situation similar to the one described above has been investigated by Gardner [36] and his results agree with those of the above calculation. However, because of the large value of $Q_{e}\left(Q_{e}=Q_{1}\right)$, it is obvious that if $C_{1}$ is in any way different from $C_{0}$ then $Q_{1} C_{t}$ will be a very different value from $\mathrm{Q}_{\mathrm{e}} \mathrm{C}_{0}$. Thus, a required condition for a trap operating in flowing water is that $\mathrm{Q}_{\mathrm{e}} \mathrm{C}_{0}=\mathrm{Q}_{1} \mathrm{C}_{\mathrm{r}}$. For these reasons it is essential for the proper operation of a sediment trap in flowing water that the concentration of particles in the water inside the trap remain the same as the concentration in the water outside.

The following example illustrates how particle concentrations inside of a trap can be different from those outside a trap and the consequences of these differences. Processes $b, c$ and $d$ listed above are also addressed in this section.

Figure $2 \mathrm{c}$ shows a trap with an inverted saucer shaped plate on top of the trap as used by Tauber [156]; it also represents a bottle shaped trap. In calm water, where $Q$ is zero, the flux of particles through the opening in the plate area, $A_{0}$, must be equal to the flux of particles to the bottom of the trap, area $A_{b}$. Rewriting equation (7), we get

$$
A_{0} V_{0} C_{0}=A_{b} V_{t} C_{t} \quad\left(M^{-1}\right)
$$

or

$$
\mathrm{C}_{\mathrm{t}}=\mathrm{C}_{0} \frac{\mathrm{A}_{0}}{\mathrm{~A}_{\mathrm{b}}} .
$$

Thus, the mean concentration of particles in the trap is inversely proportional to the relative area of the trap opening and base or, in other words, if $A_{b}>A_{0}$, then $\mathrm{C}_{\mathrm{t}}<\mathrm{C}_{0}$. This theory agrees with Gardner's [36] interpretation of overtrapping effects of bottle shaped traps in calm water. His dye experiments showed a rising plume of particle-deficient water above the mouth of the trap (fig. 3, after [36]) originating from the zones under the overhanging walls. The overhanging walls prevented new particles from entering into these zones where the particles had settled out due to gravity [36].

If this trap is now placed in flowing water (fig. $2 \mathrm{~d}$ ), and water within the trap exchanges with water outside of the trap, the concentration of particles in the trap will increase to a value $C_{t m}$ where $C_{0}>C_{t m}>C_{t}$. This interchange leads to an excess catch of particles by the trap. Equation (7) can be rewritten as

$$
A_{0} V_{0} C_{0}+Q C_{0}=A_{b} V_{t} C_{t m}+Q C_{t m}
$$

Since $V_{0}=V_{t}$, the excess catch in the trap will be given by

$$
\mathrm{V}_{0}\left(\mathrm{~A}_{\mathrm{b}} \mathrm{C}_{\mathrm{tm}}-\mathrm{A}_{0} \mathrm{C}_{0}\right)=\mathrm{Q}\left(\mathrm{C}_{0}-\mathrm{C}_{\mathrm{lm}}\right)
$$




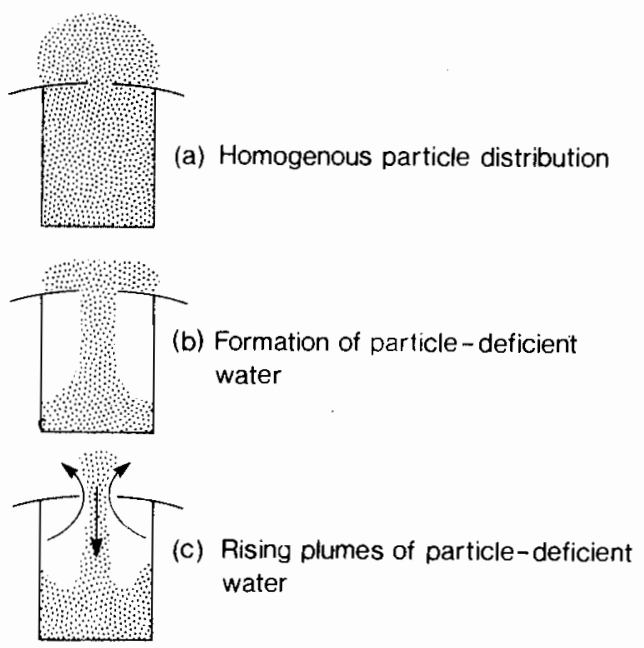

Figure 3. Schematic diagram showing overtrapping effect of particles in calm water (according to Gardner [36]).

Abb. 3. Schematische Darstellung einer flaschenförmigen Falle, die in ruhigem Wasser zu viel partikuläres Material auffängt (nach Gardner [36]). a) Homogene Partikelverteilung. b) Unter der Wölbung entsteht infolge Aussedimentierung partikelarmes Wasser. c) Das partikelarme Wasser steigt wolkenartig auf und wird durch neues, partikelreiches Wasser ersetzt.

Since $Q$ can have a very large value, a small difference between $C_{0}$ and $C_{t m}$ can still result in a large excess catch. In turbulent water where $Q$ is large, the concentration inside the trap, $\mathrm{C}_{\mathrm{tm}}$, will be close to that of the outside, $\mathrm{C}_{0}$, and the excess catch can be estimated by assuming $C_{1 m}=C_{0}$ in the left hand term of equation (12); namely $V_{0} C_{0}\left(A_{b}-A_{0}\right)$. This excess catch has been observed by Hargrave and Burns [51]. In their experiment, a trap similar to the one shown in figure $2 \mathrm{~d}$, placed in a turbulent environment, had a calculated flux rate 55 times greater than that of the uncovered cylinders. However, when the base area of the covered trap was used instead of the trap opening area in the flux calculations, the flux rate onto the bottom of the partially covered trap was found to be within $10 \%$ of the rate of the uncovered cylindrical traps.

In situ, where calm conditions alternate with turbulent situations, the effective collecting area would vary constantly between the mouth area, $A_{0}$, and the bottom area, $A_{b}$. This would mean that the effective catching area would remain unknown. For cylindrical traps in general, a period of severe turbulence would resuspend some material off the bottom and establish a concentration gradient, $\mathrm{dc} / \mathrm{dz}$, near the bottom of the trap. This would introduce a new term into equation (11) as follows

$$
\mathrm{A}_{0} \mathrm{~V}_{0} \mathrm{C}_{0}+\mathrm{Q} \mathrm{C}_{0}=\mathrm{A}_{\mathrm{b}} \mathrm{V}_{\mathrm{t}} \mathrm{C}_{\mathrm{tm}}-\mathrm{T} \mathrm{A_{ \textrm {b } }} \frac{\mathrm{dc}}{\mathrm{dz}}+\mathrm{Q} \mathrm{C}_{\mathrm{tm}}
$$

where $\mathrm{T}=$ coefficient of turbulent diffusion at the bottom of the trap $\left(\mathrm{L}^{2} \mathrm{~T}^{-1}\right)$. 
The resuspension would increase the concentration of particles in the trap so that $\mathrm{C}_{\mathrm{tm}}>\mathrm{C}_{0}$. The loss of material from the trap, because of the resuspension, would be given by $\mathrm{Q}\left(\mathrm{C}_{\mathrm{tm}}-\mathrm{C}_{0}\right)$.

If funnels were used as traps in calm water, figure $2 \mathrm{e}$, the effective collecting area would be $A_{0}$, the area of the mouth of the funnel. However, if the funnel were placed in water turbulent enough to resuspend all material settled on the sides of the funnel, then the effective collecting area would be that of the neck of the funnel, $\mathbf{A}_{\mathrm{n}}$. Since the conditions in natural waters will probably vary between calm and very turbulent, the effective catchment area would vary between $A_{0}$ and $A_{n}$ and would effectively be unknown. The funnel shape would also mean that the effective trapping area would be different for particles of different settling velocities because only flocculent particles would be retained on the funnel sides in calm water and these could later be washed out of the funnel. This undertrapping effect has been found by Gardner [36] and Hargrave and Burns [51].

As indicated above, the settling flux of particles into sediment traps depends almost entirely on their concentration and their inherent settling velocities. Turbulence does not affect the settling velocity of particles significantly, but can affect the flux if concentration gradients are present. Thus, the first design requirement following from these considerations is that sediment traps should be constructed so that concentration differences are avoided and the concentration of particles within the trap remains the same as that outside the trap in both calm and turbulent conditions. This condition requires that the trap have a simple cylindrical shape. A second basic requirement is that, once sediment has settled to the bottom of the trap it should not be resuspended by any turbulent fluctuations or, in other words, a small zone of quiescent water should always be present at the bottom of the trap. This necessitates that the cylinders have aspect ratios which increase with the degree of turbulence of the waters in which they are immersed [89]. Aspect ratios of 10 are adequate for the conditions encountered in most of the open waters of lakes and oceans.

Table 2. Influence of aspect ratio upon sediment trap catches. Lake Erie, offshore station, depth $37 \mathrm{~m}$. 'Tabelle 2. Einfuss des Verhăitnisses Höhe:Durchmesser (aspect ratio) einer Falle auf die gemeśsenen Sedimentationsraten. Erie-See, uferferne Stelle, Tiefe $37 \mathrm{~m}$.

\begin{tabular}{|c|c|c|c|c|c|c|c|c|}
\hline & Trap $\left.{ }^{1}\right)$ & 1 & 2 & 3 & 4 & 5 & 6 & 7 \\
\hline & Diameter $(\mathrm{cm})$ & 6.6 & 6.6 & 6.6 & 6.6 & 6.6 & 6.6 & 15.5 \\
\hline \multirow[t]{2}{*}{1978} & Length $(\mathrm{cm})$ & 91.4 & 132 & 91.4 & 66 & 33 & 12.7 & 50.8 \\
\hline & Aspect ratio & $14: 1$ & $20: 1$ & $14: 1$ & $10: 1$ & $5: 1$ & $2.5: 1$ & $3.3: 1$ \\
\hline \multicolumn{9}{|l|}{ Dates } \\
\hline 28.7.-10.8. & $\mathrm{g} \mathrm{m}^{-2} \mathrm{~d}^{-1}$ & 6.5 & 6.2 & 6.5 & 6.4 & 4.3 & 0.9 & 1.9 \\
\hline Retention & $(\%)$ & (101) & (97) & $(101)$ & $(100)$ & (67) & (14) & (30) \\
\hline 10.8.-21.8. & $\mathrm{g} \mathrm{m}^{-2} \mathrm{~d}^{-1}$ & 8.2 & 7.7 & 8.3 & 8.3 & 7.9 & 1.0 & 4.1 \\
\hline Retention & $(\%)$ & (99) & (93) & $(100)$ & $(100)$ & $(95)$ & (12) & (51) \\
\hline 21.8.-6.9. & $\mathrm{g} \mathrm{m}^{-2} \mathrm{~d}^{-1}$ & 6.25 & 6.3 & 6.3 & 6.6 & 3.9 & 0.4 & 2.3 \\
\hline Retention & $(\%)$ & (99) & $(100)$ & $(100)$ & (105) & (61) & (6) & (36) \\
\hline $6.9 .-20.9$ & $\mathrm{~g} \mathrm{~m}^{-2} \mathrm{~d}^{-1}$ & 8.4 & 8.1 & 8.8 & 8.6 & 9.1 & 1.5 & 3.2 \\
\hline Retention & $(\%)$ & (98) & (94) & (102) & $(100)$ & $(105)$ & (17) & (37) \\
\hline
\end{tabular}

1) Traps 2-6: The 'organ'. Traps 1 and 7: Traps of parallel moorings (within $100 \mathrm{~m}$ ). 
The in vitro and in situ experiments of Gardner [36] and Hargrave and Burns [51] confirmed this conclusion showing that the efficiency of cylindrical traps increased with rising aspect ratio up to an approximate aspect ratio of 5 , with prevailing horizontal currents of up to $10 \mathrm{~cm} \mathrm{sec}^{-1}$. Similar conclusions can be drawn from our sediment trap comparison experiments in Lake Erie, which were carried out with an organ-like set of traps having the same diameter but with different heights (table 2).

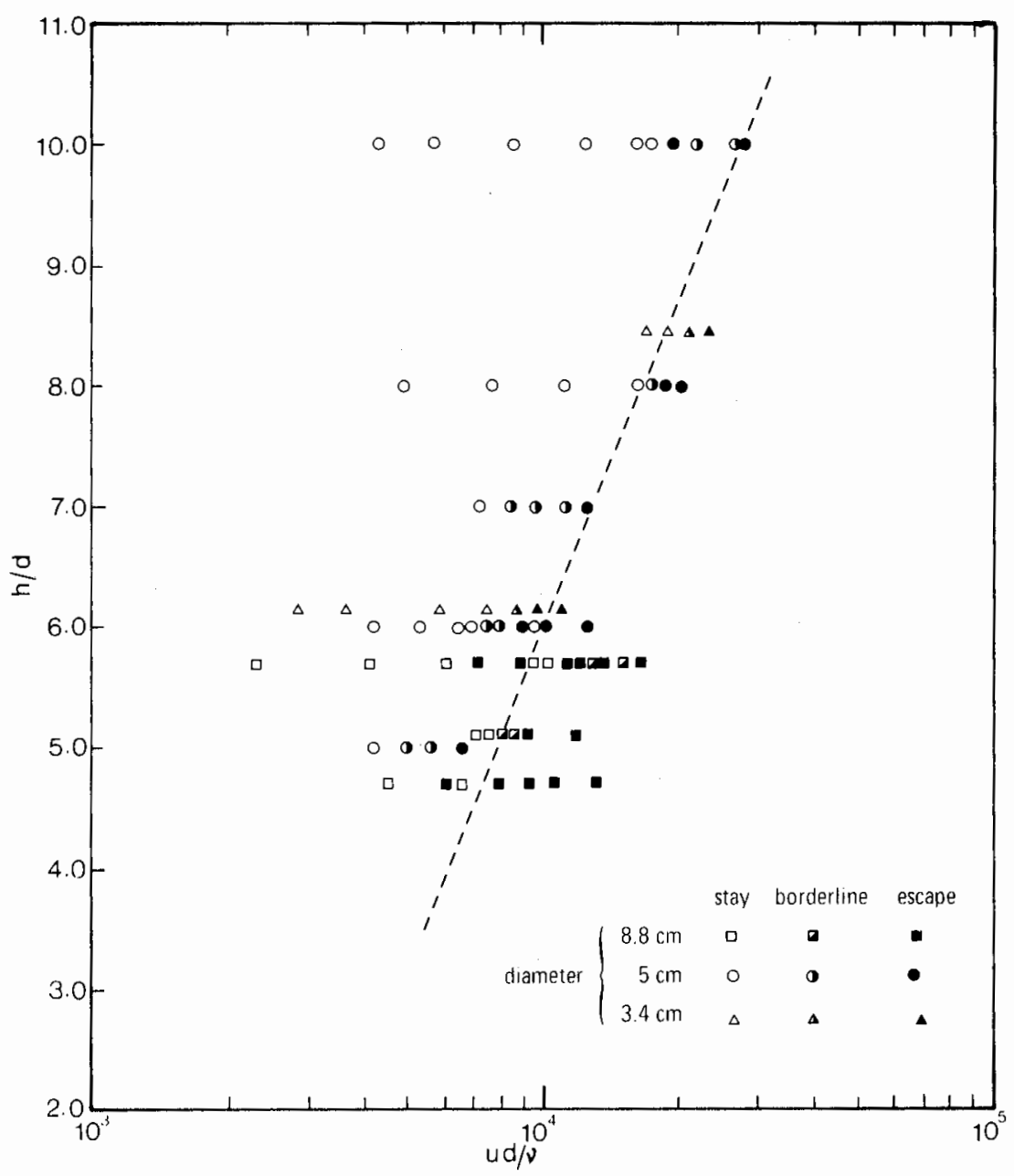

Figure 4. Dependence of resuspension of oil droplets from the bottom of a sedimentation trap on aspect ratio and flow Reynolds number (according to Lau [89]). $\mathrm{h}=$ length of cylinder, $\mathrm{d}=$ diameter of cylinder, $u=$ velocity of water flowing past the cylinder. $v=$ kinematic viscosity of water.

Abb.4. Abhängigkeit zwischen der Resuspension von Olttöpfchen vom Boden einer Sedimentfalle und dem Verhältnis Höhe: Durchmesser (aspect ratio) und der Reynolds-Zahl Re (nach Lau [89]). $\mathrm{h}=$ Höhe des Zylinders. $\mathbf{d}=$ Durchmesser des Zylinders, $\mathbf{u}=$ Fliessgeschwindigkeit des Wassers, das über den Zylinder fliesst, $r=$ Viskosität des Wassers. 
These results indicate that traps with aspect ratios of 10 or greater collected approximately the same amounts, but aspect ratios of 5 or less suffered occasional losses. The mean hypolimnion current at the offshore station would be in the order of $8 \mathrm{~cm}$ $\sec ^{-1}[197]$.

Besides the trap itself, i.e., the dimensions (h/d) of the cylinder, the flow velocity (u) and the viscosity $(v)$ of the water are also important factors influencing the catch. It is assumed that the wall roughness and the wall thickness of the trap can both be neglected if the diameter is greater than $5 \mathrm{~cm}$; if it is too narrow, overtrapping may occur. Hargrave and Burns [51] used dimensional analysis to show that the turbulence in the trap is almost completely governed by aspect ratio (h/d) and flow Reynolds number $(\mathrm{u} \cdot \mathrm{d}) / \mathrm{v}$. Lau [89] proved in more than 100 experiments with oil droplets that the resuspension in a trap depended on these two dimensionless parameters (fig. 4, after [89]). For example, we can see from figure 4 that at an aspect ratio of 5, resuspension started at a flow Reynolds number of about 7,000. If we know the in situ viscosity (temperature) of the water, we can approximate the maximum tolerable current velocity at which resuspension starts for any trap of a given aspect ratio and diameter. These values are calculated for our 'organ-traps' in Lake Erie and shown in table 3. These data indicate that current velocities of greater than $17 \mathrm{~cm} \mathrm{sec}^{-1}$ probably caused the losses of up to $35 \%$ of the catch occurring in the trap with an aspect ratio of $5: 1$. An aspect ratio of $10: 1$ is adequate for currents of approximately $30 \mathrm{~cm} \mathrm{sec}^{-1}$. Apparently, these were rarely experienced during summer in the eastern basin of Lake Erie in either the hypolimnion or at the lower border of the epilimnion in 7-25 $\mathrm{m}$ depth. This is in accordance with known water transports in the area [186]. The data in tables 2 and 3 give an idea of the maximum current operating at the offshore station during the different periods. This use of different aspect-ratio sediment traps as turbulence monitors was suggested by Hargrave and Burns [51].

Table 3. Calculation of the maximum horizontal flow velocity ( $\mathrm{cm} \mathrm{sec}^{-1}$ ) above which resuspension begins, having a given trap diameter and Reynolds number $(\mathrm{Re})$.

Tabelle 3. Berechnung der maximalen horizontalen Fliessgeschwindigkeit ( $\mathrm{cm} \mathrm{sec}^{-1}$ ), oberhalb welcher Resuspension in der Falle beginnt (bei gegebenem Fallendurchmesser und gegebener Reynolds-Zahl Re).

\begin{tabular}{|c|c|c|c|c|c|c|}
\hline Aspect ratio & $20: 1$ & $14: 1$ & $10: 1$ & $5: 1$ & $2.5: 1$ & $3.3: 1$ \\
\hline Diameter $(\mathrm{cm})$ & 6.6 & 6.6 & 6.6 & 6.6 & 6.6 & 15.5 \\
\hline $\begin{array}{l}\text { Re-number at which } \\
\text { resuspension starts }{ }^{1} \text { ) }\end{array}$ & 70,000 & 35,000 & 20,000 & 7,000 & 4,500 & 5,000 \\
\hline $\begin{array}{l}\left.\text { Mean catch }(\%)^{2}\right) \\
\text { Critical horizontal } \\
\text { flow velocity }\left(\mathrm{cm} \mathrm{sec}^{-1}\right)\end{array}$ & 100 & 100 & 100 & $65-100$ & $5-20$ & $30-50$ \\
\hline at $4^{\circ} \mathrm{C}$ & 166 & 83 & 47.5 & 16.6 & 10.7 & 5.1 \\
\hline at $10^{\circ} \mathrm{C}$ & 139 & 69 & 39.6 & 13.9 & 8.9 & 4.2 \\
\hline at $20^{\circ} \mathrm{C}$ & 106 & 53 & 30.3 & 10.6 & 6.8 & 3.2 \\
\hline
\end{tabular}

1) From Lau's [89] diagram (fig.4); $\mathrm{Re}=(\mathrm{u} \cdot \mathrm{d}) / \mathrm{l}^{\prime}$. where $u=$ current velocity, $\mathrm{d}=$ diameter, $\mathrm{l}^{\prime}=$ kinematic viscosity, $\quad\left(4{ }^{\circ} \mathrm{C}\right)=1.5, \prime^{\prime}\left(10^{\circ} \mathrm{C}\right)=1.3, \cdots\left(20^{\circ} \mathrm{C}\right)=1.0$.

2) From table 2 . 
It should be remembered that there is a continual flow of water and particles through a trap sited in flowing water. This flow does not affect the downward flux of particles but it can drastically change the measured flux rate if either of the above requirements of cylindrical shape or nonresuspension are violated.

Before concluding this section, the possible error in this analysis should be considered when the basic assumption that turbulence does not affect the settling velocity of particles is not completely correct; as in the case of particles having Re values of greater than 0.5 .

If the settling velocity in turbulent water is different from that in calm water, then the number of particles settling into the trap through the turbulent water at the mouth will be different from the number settling onto the bottom from the calm water near the bottom. This means that even in a cylindrical trap the concentration inside the trap, $C_{t}$, can be different from that outside the trap, $C_{0}$. Rewriting equation (7) we get

$$
\begin{aligned}
C_{t}\left(A_{0} V_{t}+Q\right) & =C_{0}\left(A_{0} V_{0}+Q\right), \\
C_{t} & =C_{0} \frac{\left(A_{0} V_{0}+Q\right)}{\left(A_{0} V_{t}+Q\right)} .
\end{aligned}
$$

Equation (15) gives the dependence of the two concentrations on the two different settling velocities and the flow of particles through the trap. When the conditions at the mouth of the trap are calm or mildly turbulent, $V_{0}$ would be essentially equal to $V_{t}$ and the two concentrations would be equal. This means the flux would be $\mathrm{F}_{\mathrm{t}}=\mathrm{A}_{0} \mathrm{~V}_{\mathrm{t}} \mathrm{C}_{0}$, which is the calm water settling flux. Taking the other extreme of very turbulent conditions around the mouth of the trap means that $\mathrm{V}_{0}$ may be significantly different from $V_{t}$, but it also means that there will be much exchange of water in and out of the trap. Since the value of $Q$ will be very large in this case, the $\left(A_{0} V_{0}+Q\right)$ term will be almost the same as the $\left(A_{0} V_{t}+Q\right)$ term, and again $C_{t}$ will be approximately equal to $C_{0}$. The result of this is that even when turbulence effects prevail, the flux rate will again be the calm water flux rate, $F_{t}=A_{0} V_{t} C_{0}$. Thus, if turbulence of the magnitude experienced in a certain flow regime is found to decrease the settling velocity by $5 \%$, then the flux rate calculated from the trap will be about $5 \%$ too high because $V_{t}$ will be $5 \%$ higher than $V_{0}$. The correction can easily be made. A similar type of correction can be applied for different particle sizes if the range of particle Reynolds numbers are calculated for the particles in the water surrounding the trap. The effects of the turbulence can then be estimated for the particles having Reynolds numbers greater than 0.5 .

In this brief discussion of the effect of turbulence on the settling velocity of particles it is important to mention that the organized flows of water in Langmuir cells in the epilimnion can provide a mechanism for suspending slowly settling particles indefinitely and can also reduce the net settling velocity of larger particles. This mechanism, described in detail by Titman and Kilham [201], basically reduces the settling rate of particles as they repeatedly settle from circulation cells having higher relative upwelling velocities to others having lower relative downwelling velocities. 
This suspending action of organized Langmuir cells is completely different from the action by which turbulence reduces the settling velocity of particles.

Sediment traps will over-collect particles if they are placed in Langmuir cells because they will collect at the normal rate for calm or mildly turbulent water. There are no means by which traps can be made to compensate for the suspending effects of the Langmuir circulations. Further, there is no simple method for calculating the extent of overtrapping by a sediment collector placed in Langmuir circulations.

Scott et al. [196] found that Langmuir circulations only reached the thermocline during periods of relatively strong winds. During normal winds the circulations would remain in the upper parts of the mixed layer on the epilimnion. This means that a reasonable estimate of flux from the epilimnion can be obtained for many of the periods of exposure if the trap is set just above the thermocline. However, it also means that a profile of fluxes calculated from a vertical series of traps set within an epilimnion is probably meaningless.

\section{Results from multiple sediment trap experiments}

Reviewing sediment trap literature, one can find some papers where trap efficiency tests have been methodically performed $[21,36-38,51,74,84,89,115,117,154-156$, $169,174]$, or where trapping efficiency has been seriously discussed $[1,7,62,114$, $143,145,152]$. These studies provide information to test some of the results of the foregoing theoretical analysis.

A historical review reveals that in earlier times simple metal boxes or containers [57, 68, 121, 123-125, 142] (Petersen [118] used metal cylinders), cans [33] or glass jars $[73,98,139,151]$ were used. Later, some more complex and unusual constructions were used [1, 3-7, 46, 48, 85, 94, 95, 144, 157, 164]. However, during the past 20 years, wide-mouthed jars, funnels and cylinders, became the most frequently used trap design (table 4). Only very recently a new development, namely the introduction of reference chambers (see chap. 4 and $[27,35,83,122,147,174]$ ) has occurred.

\section{Comparison of fluxes from different trap designs}

The physical theory, outlined in the preceding section, and the cited in vitro experiments, recently performed by Gardner [36] and Hargrave and Burns [51], both show us that the cylindrical trap is the most efficient among the different trap designs used. The term efficiency refers to the avoidance of undertrapping or overtrapping. If we want to know if a trap catches the real flux of particulate material, we have to compare its collecting flux with the flux to the total bottom area of the experimental container. The flume experiments of Gardner [36] as well as the tests in a settling tank of Hargrave and Burns [51] have shown that the cylindrical trap measures a flux rate closest to the noninfluenced sedimentation rate.

We can expect that a properly proportioned cylinder collects about $95-100 \%$ [36] of the real sedimentation rate. Funnels generally underestimate under turbulent conditions $(25-60 \%, 1 . c$.$) , but this can be slightly improved if baffles are fixed at the$ top of the funnels to reduce turbulence $(60-90 \%, 1 . c$.$) . Narrow-mouthed traps with$ wide bodies (bottle type) overtrap at different degrees depending on the geometry 
and the ratio between the area of the opening and bottom $(230-1,000 \%$. l.c.) when the area of the mouth opening is considered as the effective trapping area. However, in flowing waters the catches are in the range of those of a cylindrical trap, if the bottom area is considered to be the effective trapping area [51]. Tray-like containers collect only a small fraction $(2-12 \%,[36])$ of the real amount due to unhindered resuspension. Their low efficiency is so apparent that they need no further discussion.

Johnson and Brinkhurst [74] found sedimentation rates which increased in the following order: large funnel $(\mathrm{d}=41 \mathrm{~cm})<$ regular funnel $(\mathrm{d}=20 \mathrm{~cm})<$ large cylinder $(\mathrm{d}=17 \mathrm{~cm})<$ small funnel $(\mathrm{d}=12 \mathrm{~cm}) \ll$ small cylinder $(\mathrm{d}=5 \mathrm{~cm})$, confirming the theory that funnels and cylinders with insufficient aspect ratio undertrap consistently.

Pennington [117] reported that funnels undertrapped due to resuspension (see also Tutin [167]). She also found that Tauber traps with collars [156] caught an average of 2.4 times more material than cylinders in the turbulent epilimnion and during

Table 4. Sediment trap references classified in terms of trap geometry and field of exposure. The numbers correspond to the number of the reference in the references section $I$.

Tabelle 4. Sedimentfallenliteratur geordnet nach Fallengeometrie und Ort des Einsatzes. Die Zahlen entsprechen den Referenzzahlen im Literaturverzeichnis I.

\begin{tabular}{|c|c|c|c|c|c|c|c|}
\hline & Cylinders & $\begin{array}{l}\text { Cylinders } \\
\text { with } \\
\text { funnel } \\
\text { base }\end{array}$ & Funnels & $\begin{array}{l}\text { Wide- } \\
\text { mouthed } \\
\text { jars }\end{array}$ & $\begin{array}{l}\text { Bottles } \\
\text { and } \\
\text { similar } \\
\text { vessels }\end{array}$ & $\begin{array}{l}\text { Containers } \\
\text { or pans }\end{array}$ & $\begin{array}{r}\text { Others or } \\
\text { unknown con- } \\
\text { figuration }\end{array}$ \\
\hline Lake & $\begin{array}{l}8-11, \\
13,17-19, \\
26,27, \\
33-36, \\
38.40, \\
74,82-84, \\
96,97, \\
101.116, \\
117,122, \\
131-133,167 \\
173-175\end{array}$ & $\begin{array}{l}\text { 1. 28, } 75 \\
80,81,88 \\
106,107\end{array}$ & $\begin{array}{l}14,16,36, \\
38,56,74, \\
87,93,97, \\
99,117 \\
126-128, \\
141,148, \\
150,167 \\
168,170\end{array}$ & $\begin{array}{l}21-25 \\
28,30 \\
36,38, \\
73,76-79, \\
90 \\
92,100 \\
103,139 \\
151,163 \\
172\end{array}$ & $\begin{array}{l}12,36,38 \\
46,47,60 \\
105,111 \\
117,129 \\
136,137 \\
168\end{array}$ & $\begin{array}{l}3-5,45, \\
48,49 \\
57,85,86, \\
123,124, \\
157-162, \\
168\end{array}$ & $\begin{array}{r}59,71,72 \\
109\end{array}$ \\
\hline Ocean, open & 39,134 & 70,104 & $\begin{array}{l}58,62-64 \\
143,145 \\
180\end{array}$ & & & $\begin{array}{l}61,65,94 \\
95,176\end{array}$ & \\
\hline $\begin{array}{l}\text { Ocean, shelf } \\
\text { (bay, fjord, } \\
\text { lagoon, reef. } \\
\text { sea loch, } \\
\text { estuary) }\end{array}$ & $\begin{array}{l}20,36,38 \\
50.51,53 \\
54,67,102 . \\
108,110 \\
118-120 \\
144,146 \\
153,164 \\
171,177 \\
178\end{array}$ & $\begin{array}{l}165,166 \\
179\end{array}$ & $\begin{array}{l}6,7,36 \\
38,51,112 \\
138\end{array}$ & $\begin{array}{l}2,29,36 \\
38,55,98 \\
140,147 \\
149\end{array}$ & $\begin{array}{l}36,38,42 \\
43,51,114 \\
121\end{array}$ & $\begin{array}{l}31,51,68, \\
125,130 . \\
142\end{array}$ & $\begin{array}{r}32,69,135 \\
142,169\end{array}$ \\
\hline Laboratory & $\begin{array}{l}36,37,51, \\
89\end{array}$ & & $36,37,51$ & $36,37,66$ & $\begin{array}{l}36,37,51, \\
115\end{array}$ & $36,37,51$ & 51 \\
\hline Air (pollen) & 154 & & & & 155,156 & & \\
\hline
\end{tabular}


overturn periods when the mouth area was considered as the basis of her calculations. However, if the bottom area is taken as the collecting area and used as the basis for the flux calculations, the Tauber traps give a value in the range of those obtained by the cylinders ( 0.7 of the value for the cylinders). In this regard her results are similar to those obtained by Hargrave and Burns [51]. Pennington [117] did not use the Tauber trap results but those from the cylindrical traps (aspect ratio 3.7) in computing the annual sedimentation rates for Lake Windermere. These rates agreed with sedimentation rates calculated by three other methods. She also concluded that there was very little resuspension of particulate material in this lake. Steele and Baird [147] compared open jars (h:d=85 $\mathrm{mm}: 81 \mathrm{~mm}=1.05: 1)$ with tubes and got higher amounts of material with a longer tube $(300 \mathrm{~mm})$ and less amounts with a smaller tube $(200 \mathrm{~mm})$ than with the jars. Since no tube diameters are given, we only can assume that the smaller tube as well as the jars were undertrapping due to inadequate aspect ratios.

Very recently Ulén [168] compared funnels, trays and cylinders with collar opening in Lake Norrviken. He reported that the funnel-shaped trap collected half as much than the cylindrical trap during stratification, and only $5 \%$ during turnover; the tray contained only $20 \%$ of the amount collected by the cylinder during stratification.

Ohle [107] cited Mitjagina [97] who came to the conclusion that cylinders are more useful than funnels, but did not give more information. Moore [98] and Mueller [100] used different traps, but implied differences in their efficiency as nonexistent. Unfortunately there are only a few papers which have made comparisons of the collection efficiency of different types of traps but these studies do generally confirm the foregoing theoretical analysis.

\section{Comparison of fluxes from cylinders with different aspect ratios}

Our experiments in Lake Erie, which is fairly turbulent, showed us that differing trap size (change in height) can result in significant undertrapping as soon as the aspect ratio is smaller than 5:1 or 10:1 (see chap.2). Also a comparison of the regular tubes $(\mathrm{h}: \mathrm{d}=132 \mathrm{~cm}: 6.6 \mathrm{~cm}, A . R .=14: 1)$ with wider tubes having an insufficient aspect ratio $(\mathrm{h}: \mathrm{d}=50.8 \mathrm{~cm}: 15.5 \mathrm{~cm}, \mathrm{~A} . \mathrm{R} .=3.3: 1)$ gave the same result: the losses varied during the summer/autumn period with changes in the mixing regime, and were higher in the more turbulent epilimnion (69-98, mean 91\%) than in the less turbulent hypolimnion (42-92, mean $71 \%$ ).

On the other hand, by changing the diameter instead of the height, Davis [21], Watanabe and Hayashi [170], Young and Rhoads [178], White and Wetzel [174] and Kirchner [84] could not find a significant effect of the sediment trap size on the flux of material, thus they considered sedimentation rate to be directly proportional to the collecting area. If their statement is correct, we can assume that the aspect ratio of their traps must have been sufficient to prevent resuspension in their measurements. However, Kirchner's [84] high coefficients of variation $(\rho /$ mean $=12-72 \%)$ of supposedly equivalent flux rates (his table 2), may originate from partly inadequate aspect ratios $(0.6-7.8: 1)$. In contrast to large diameter traps, Davis [21] found the tendency of narrow traps to overtrap due to wall effects, and she convincingly confirmed her laboratory experiments with pollen by in situ measurements. She 
made the same experiments (catching pollen) in the laboratory (her fig. 2) and later in the lake (her fig.3).

\section{Comparison of fluxes from identical parallel traps}

Our experiments in Lake Erie during summer 1978 showed that the differences between 5 parallel cylindrical traps were small (mostly within $\pm 10 \%$ ), and even parallel moorings within about $100 \mathrm{~m}$ gave the same results (table 5). We also found that the variation differed from one chemical component to another, increasing slightly in the order of dry weight, POC, PN, PP and Chl $a$. This is in agreement with Kimmel and Goldman [82] but not with Webster [171] and Dörrstein [27]. who found the variation in POC and PC. PN and PP, respectively, to be in the same order or even less than the variation in dry weight measurements.

Traps have often (40 reports) been used in duplicates or even up to eight replicates at the same site, but many authors ( 17 papers) gave no information about the variation.

Where results were mentioned. differences were reported to be either significant (5 papers) or insignificant (16 papers). Even though many authors presented their data in a rather confusing manner, it is obvious that the standard deviation of

Table 5. Accuracy of parallel trap catches (5 tubes). Lake Erie, inshore (depth: 7-8 m), mid (depth: $25 \mathrm{~m}$ ) and of shore stations (depths: $10,20,32$ and $37 \mathrm{~m}$ ), 28.6-10.10.78. Total measurements: 30 .

Tabelle 5. Genauigkeit von Parallelmessungen mit 5 Fallen. Erie-See, ufernahe (Tiefe: 7-8 m), mittlere (Tiefe: $25 \mathrm{~m}$ ) und uferferne Stelle (Tiefen: 10,20,32 und $37 \mathrm{~m}$ ). 28.6.-10.10.78. Total 30 Messungen.

\begin{tabular}{lrrrrrr}
\hline & D.W. & POC & PN & PP & $\begin{array}{c}\text { Chl } a \\
\text { uncorr. }\end{array}$ & $\begin{array}{r}\text { Chl } a \\
\text { corr. }\end{array}$ \\
\hline $\begin{array}{l}\text { Coefficient of variation } \\
(\sigma / \text { mean })\end{array}$ & & & & & & \\
$<5 \%$ & 21 & 4 & 6 & 11 & 12 & 7 \\
$5-10 \%$ & 9 & 20 & 17 & 8 & 9 & 10 \\
$10-15 \%$ & - & 5 & 7 & 5 & 4 & 3 \\
$15-20 \%$ & - & - & - & - & 3 & 6 \\
$>20 \%$ & - & $\left.1^{\prime 1}\right)$ & - & $\left.6^{\prime}\right)$ & $\left.2^{\prime}\right)$ & $\left.4{ }^{\prime}\right)$ \\
\hline
\end{tabular}

1) Most of these high coefficients of variation can be explained by analytical error, since cancelling one of the 5 analysis values brings them below $15 \%$.

Example: Offshore station, depth $37 \mathrm{~m}$ ( $3 \mathrm{~m}$ above bottom), dry weight, $\mathrm{g} \mathrm{m}^{-2} \mathrm{~d}^{-1}$.

\begin{tabular}{lllll}
\hline $\begin{array}{l}\text { Time period } \\
1978\end{array}$ & Days & Sedimentation rates & Mean \pm S.D. & $\begin{array}{l}\text { Sedimentation rate } \\
\text { of a nearby trap }\end{array}$ \\
\hline 28.6.-12.7. & 14 & $4.20 / 4.36 / 4.27 / 4.34 / 4.32$ & $4.30 \pm 0.06$ & - \\
$12.7 .-28.7$. & 16 & $5.12 / 5.16 / 5.08 / 5.11 / 5.09$ & $5.11 \pm 0.03$ & 5.15 \\
$28.7-10.8$. & 13 & $6.54 / 6.65 / 6.41 / 6.50 / 6.57$ & $6.53 \pm 0.09$ & 6.48 \\
$10.8 .-21.8$. & 11 & $8.22 / 8.40 / 7.97 / 8.23 / 8.16$ & $8.20 \pm 0.15$ & 8.28 \\
$21.8 .-6.9$. & 16 & $6.34 / 6.43 / 6.07 / 6.19 / 6.23$ & $6.25 \pm 0.15$ & 6.29 \\
$6.9 .-20.9$. & 14 & $8.63 / 8.80 / 8.74 / 8.15 / 7.76$ & $8.42 \pm 0.45$ & $9.05 / 9.05 / 8.60 / 8.84 / 8.95$ \\
& & & & mean \pm S.D. $=8.90 \pm 0.19$ \\
& & & 8.77 \\
$20.9 .-10.10$. & 20 & $9.89 / 9.90 / 9.75 / 9.79 / 9.72$ & $9.81 \pm 0.08$ & 9.38 \\
\hline
\end{tabular}


replicate catches was usually within $10 \%$ and seldomly exceeded $20 \%$ (see e.g. [14, $27,53,55,82,117,119,171,173]$ ). Only the results of Fuhs [35], Glynn [42] and Ott [110] show large differences. Spencer et al. [145] and Honjo [62] found differences in duplicate deep sea exposed traps to be related to the smallest size fraction of particles $(<10 \mu \mathrm{m})$.

Parallel moorings have been deployed as well as replicate traps. Steele and Baird [147] (in a Scottish Sea Loch), Gasith [40] (in a small, shallow eutrophic lake) and Ravera and Viola [122] (in Lake of Lugano) obtained similar results to ourselves (table 5). The experiences of Deevey [25] (in a small lake), Smetacek et al. [143] (ocean) and Zeitschel et al. [180] (ocean) are not known. However, in some lakes, significant differences in settling fluxes measured by parallel traps in neighbourhood moorings could be found ([83] and J. Davies, personal communication). In small lakes, the site of the mooring is of great importance since sedimentation rates may be influenced by horizontal currents [83] and/or the sediment focussing effect (socalled funnel or 'Trichter' effect $[16,106])$.

\section{Conclusions ,}

To summarize this section, we can conclude from laboratory experiments and in situ measurements that funnels definitely undertrap significantly. Cylinders are the best type of sediment trap configuration, since bottles are linked with a tendency to overtrap in both calm and turbulent waters. The diameter and aspect ratio of cylindrical traps was found to be of crucial importance (e.g. [21, 84]) which is in agreement with the above theoretical deductions (chap.2). Further, it is demonstrated that identical parallel traps usually give satisfactory results within $10 \%$ of each other.

\section{The practical aspects of sediment trap design}

Theoretical considerations (chap.2) and trap experiments with sediment traps (chap.3) lead to the conclusion that sediment traps for use in lake studies should consist of well-proportioned cylinders. Other important practical aspects also remain to be discussed, such as the materials to be used, the accessories considered to improve trap efficiency (collars, lattices, baffles, lids, reference chambers), the use of preservatives, appropriate exposure times and sites, mooring systems, the procedure of retrieving the traps and sampling of the material from the traps and the preparation of the trapped material for analysis (i.e. taking the material out of the trap).

We do not consider the use of traps in deep oceans $(>500 \mathrm{~m})$ here because they may necessitate different configurations than we recommend, also because of the technical problems of oceanic mooring systems, and of the high static pressures. In oceans particulate material is much less abundant than in lakes and consists mainly of large particles (fecal pellets), thus it is often necessary to concentrate the material in order to collect reasonable amounts. Recently Zeitschel et al. [180] and Honjo [62] and Spencer et al. [145] have developed and used a special deep sea trap with adjustable timing and closing equipment. The trap consists of a funnel (for particle concentration) with a baffled cylinder at the top, and is similar in function to a 
simple cylindrical trap [36]. Further traps for deep oceans have been described by Berger and Soutar [7], Nishizawa and Izeki [104], Izeki [70], Wiebe et al. [176], Soutar et al. [144], Gardner [36], Gardner et al. [39], Staresinic et al. [146] and Rowe and Gardner [134].

\section{Material}

Obtaining suitable material is no longer a problem. Metals, used in early studies, are not recommended because of corrosion and sample contamination and glass is usually avoided because it is too fragile and interferes with phosphorus analyses. The modern traps are made of either transparent or nontransparent PVC or plexiglass-tubes which are easily available. If organochlorine and hydrocarbons are to be analyzed, glass or teflon-coated materials must be used to prevent contamination.

\section{Collars}

Sloping collars, fixed at the opening of the cylinder to minimize turbulence in this area $[51,115,117,143,155,156,167,180]$ introduce new problems, because the collar transforms the cylinder-shaped trap into a bottle-shaped trap with the resultant tendency to overtrap as shown above. If the collar opening is the same as that of the cylinder, the collar may still cause problems by collecting material on it during quiescent periods which material can subsequently be washed into the trap when currents occur. If we consider the correction of Hargrave and Burns [51] which is to take the bottom area as the collecting area instead of the mouth area in turbulent environments and which brings collar trap catches into the range of cylindrical traps, we find no advantage to collars. Thus we see no reason to unnecessarily complicate a simple system which works well.

\section{Lattices}

Wide-meshed lattices or screens recommended by Thomas [161], Rhoads and Young [130] and Fuhs [35] to prevent loss of sediments by the activity of fish and crayfish should not be used because they diminish the collecting area when covered with attached growth ('Aufwuchs'). Also this material can fall into the trap. However, the appropriate procedure in this matter is dependent on the site.

\section{Baffles}

Baffles in the cylinder are thought to diminish turbulence within the trap. They can either be very narrow cylinders (diameter about $2 \mathrm{~cm}$ or less) of the same height as the trap cylinder itself and packed into it, or a smaller bent aluminum piece or a waffle-like grill at the bottom of the trap (fig.5). Baffles have not been reported frequently in the literature. Emery et al. [31] and Rhoads and Young [130] used baffles on the bottom of pans and boxes, respectively. Anderson [1] and Gardner [36] used baffles at the top of funnels, improving the catch efficiency from $25-60 \%$ to $60-90 \%$ [36]. Gardner's traps were prototypes of Honjo's deep sea traps [62, 145]. 
Sketch of the small aluminium baffles used during investigations in Lake Erie, 1978. (see table 6)
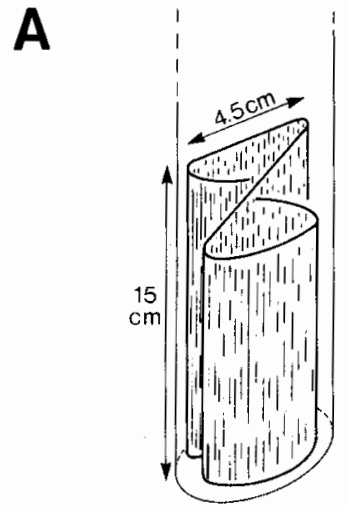

For comparison : a group of long narrow baffle tubes, used by HARGRAVE and BURNS [51]

8

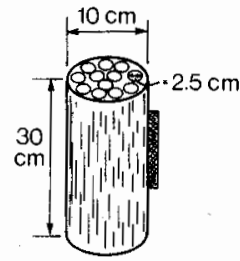

A waffle-like grill, used by
EMERY et al. [31]

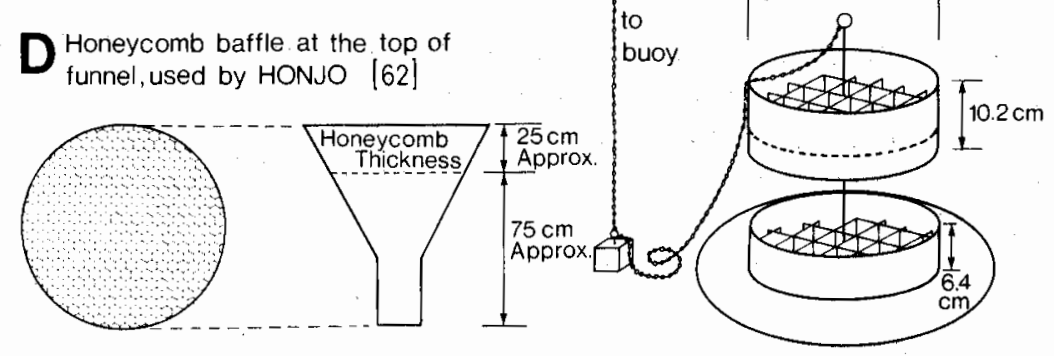

Figure 5. Various types of baffies used in sediment traps.

Abb. 5. Verschiedene Formen von Falleneinsätzen zur Verminderung von Turbulenzen. $A=$ Aluminiumeinsätze. wie sie bei unseren Untersuchungen auf dem Erie-See 1978 verwendet wurden (vgl. Tab.6).

Zum Vergleich: B == ein Bündel von langen, engen Einsatzröhren nach Hargrave und Burns [51]; C = ein waffelartiges Gitter nach Emery et al. [31]; D = ein bienenwabenartiges Gitter, aufgesetzt am oberen Rand eines Trichters, nach Honjo [62].

The idea of setting baffles in cylinders originates from Burns [13] who used a settling velocity bottle [181] with a group of narrow subcylinders inside to reduce circulation within the chamber. Hargrave and Burns [5l] found slightly increased sedimentation rates in a series of traps with baffles getting smaller in diameter, but this effect occurred only in situ, not in vitro, and the differences are not significant. Lau [89] described an upwelling effect in the middle baffle tubes in his dye experiments. In Lake Erie (table 6) during the period July to September 1978, baffles introduced into traps with an aspect ratio of 14 had no effect on the trap efficiency.

If traps with appropriate aspect ratios are used there is no need for baffles. 
Table 6. Influence of baffles (fig. 5A) upon trap efficiency. Lake Erie, 28.6.-19.9.78. Dry weight, $\mathrm{g} \mathrm{m}^{-2} \mathrm{~d}^{-1}$. Tabelle 6. Einfluss von Aluminiumeinsätzen (Abb.5A) auf die Falleneffizienz. Erie-See, 28.6.-19.9.78.

Trockengewicht, $\mathrm{g} \mathrm{m}^{-2} \mathrm{~d}^{-1}$.

Total measurements: 24

Magnitude of differences with or without baffles:

Number of incidences:

0

$<5 \%$

$5-8 \%$

Examples:

\begin{tabular}{lllccr}
\hline $\begin{array}{l}\text { Time period } \\
1978\end{array}$ & Days & $\begin{array}{l}\text { Station } \\
\text { number }\end{array}$ & $\begin{array}{l}\text { Depth } \\
\mathrm{m}\end{array}$ & $\begin{array}{l}\text { With baffles } \\
\text { 3 tubes }\end{array}$ & $\begin{array}{r}\text { Without baffles } \\
\text { 2 tubes }\end{array}$ \\
\hline $12.7 .-28.7$. & 16 & Offshore & 7 & 0.74 & 0.79 \\
$12.7 .-28.7$. & 16 & Offshore & 37 & 5.2 & 5.1 \\
$8.9 .-19.9$. & 11 & Mid-station & 25 & 20.4 & 21.3 \\
$8.9 .-19.9$. & 11 & Inshore & 8 & 112.5 & 114.7 \\
\hline
\end{tabular}

\section{Lids}

An unsettled debate exists about whether one should close a trap before retrieving it. The major reason for closing a trap after exposure is to prevent possible loss of collected material by turbulent currents created during retrieval. Generally a messenger is dropped from the surface, closing the trap before retrieval, but sometimes the traps are closed and recovered by divers $[2,13,36,55$ (closed?), 102, 110, 112 (closed?), 130, 147, 149 (closed?). 171, 178].

Besides caps, a great number of different closing systems are reported in the trap literature. They range from simple but bulky falling lids $[5,20,73,157]$ to any number of inventions $[4,35,48,61,62,65,68,82,83,85,94,95,103,120,121,134$, $145,164,176]$.

The disadvantage of lids is that they are complicated in construction or use and possibly interfere with the correct settling flux in the region of the trap opening (e.g. the trap of Thomas [157] with a vertically positioned lid; this is greatly improved by the horizontally rotating closing mechanism of Kimmel's [83] trap, but here the fittings on the support line may interfere). Furthermore, Scuba divers, though useful, can only be engaged in shallow water to about $30 \mathrm{~m}$ depth and are not available everywhere.

The main advantage of closing systems, however, is deemed questionable by the bulk of observations made by numerous authors while retrieving traps without lids (e.g. $[9,21,22,27,55,60,73-75,117,139,167,171])$. A visible disturbance was never seen in the overlying water, and the collected sediment was described as an undisturbed, discrete layer at the bottom of the trap. Even the addition of sodium chloride $(\mathrm{NaCl})$ to build up a stable density gradient at the bottom, as used by Rigler et al. [131] and Kirchner [84], is not necessary. The observations of Bloesch [8] when comparing orthophosphate (SRP) concentrations in the overlying water column in the trap with those in the lake water indicated that approximately the upper half of the trap (length of $50 \mathrm{~cm}$ ) was mixed and the lower half remained 
calm and was not disturbed by artificial eddies during retrieval. Dörrstein [27] came to the same conclusion in a similar experiment. If the aspect ratio of a cylindrical trap is higher than 5 and is good enough to prevent resuspension during exposure, then it will also prevent resuspension during hauling up of the trap in most limnological investigations. Deep ocean experiments may require trap lids. Because the closing systems in general may introduce more sources of error than help avoid error, we consider lids unnecessary for most limnological investigations.

\section{Attached growth (reference chambers)}

During the course of trap development, a new type of trap equipped with a reference chamber has recently evolved $[27,35,83,122,147,174]$. The idea is to correct the obtained sedimentation rates by a factor for the attached growth ('Aufwuchs'), measured simultaneously in the reference trap. The reference portion of the trap has the opening at the bottom (fig. 6). The growth on the walls of the lower (reference) trap is collected quantitatively and subtracted from the catch in the upper (sedimen-

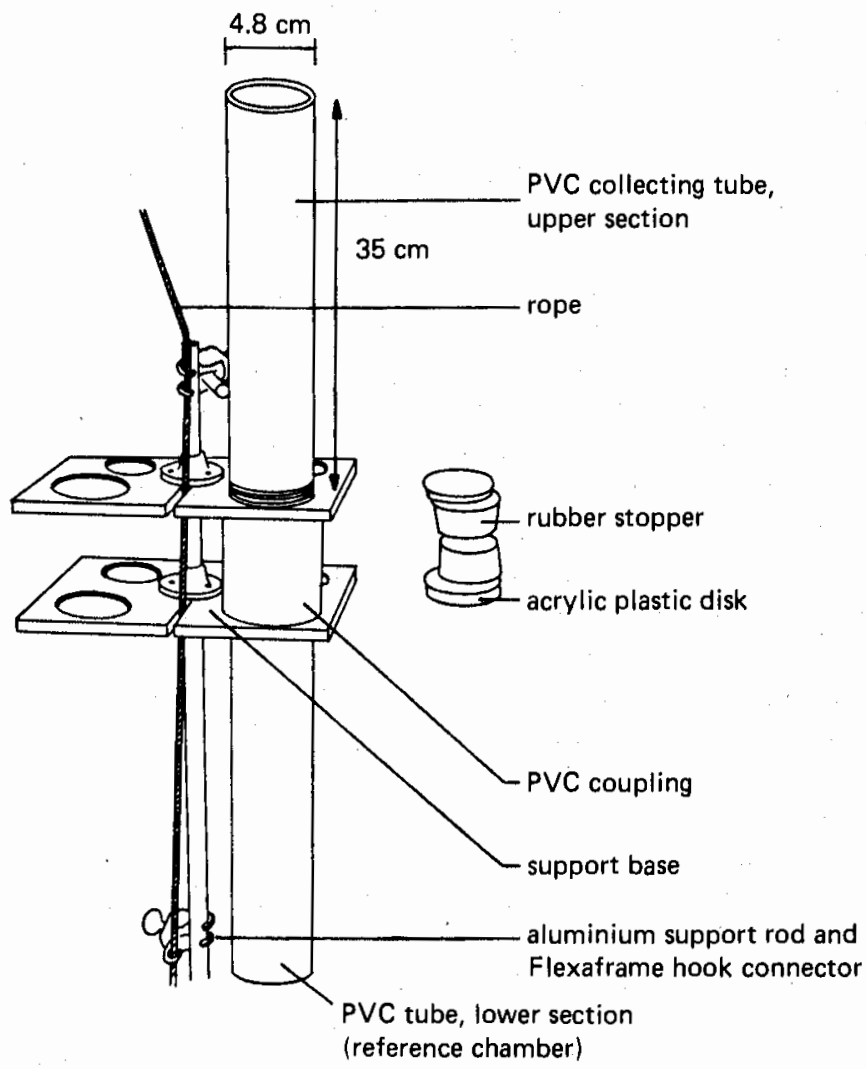

Figure 6. Sediment trap used by White and Wetzel [174] for correction of attached growth ('Aufwuchs'). Abb.6. Sedimentfalle mit Referenzkammer (Offnung nach unten) zur Korrektur des Aufwuchses, verwendet von White und Wetzel [174]. 
tation) trap to correct for material attached to the walls of the upper trap which may have fallen into the samples.

It is well known that the walls of a trap within the trophogenic zone will be covered by a slimy, thin layer of attached growth ('Aufwuchs') within a few days. Usually, when the sample is taken out of the tube the majority of this layer stays hanging on the walls and is never added to the collected material, especially if the water is drained gently from the trap. Further, Dörrstein [27] found that new problems arise when zooplankton and blue-greens migrate in to the reference chamber. It seems that the use of a reference trap is likely to introduce as much error as it will alleviate with the added disadvantage of requiring more complex equipment and technique.

\section{The problem of artificial mineralization (preservatives, exposure time)}

Having rejected all kinds of trap accessories and using a simple cylindrical tube with a satisfactorily high aspect ratio, we now come to another point of discussion, namely that of the changes in a sample while sitting in a sediment trap. The higher the aspect ratio, the more the tube becomes similar to a closed system, especially the bottom layer which will be separated completely from the surrounding water. This calm zone, excluded from all natural water movements, may be a favoured place to enhance bacterial mineralization. Psenner [195] found that zymogenic bacteria within the traps of Dörrstein [27] were about 1,000 times higher in number than in the free water mass of Lake Piburg $\left(50 \times 10^{3}\right.$ to $250 \times 10^{3}$ colonies $\left./ \mathrm{ml}\right)$, thus indicating a possible increase of decomposition in the trap. A quantitative as well as a qualitative alteration of the trapped material would then be possible [44, 52]. Furthermore, the conditions in the trap could be seriously altered from the natural ones by attracted zooplankton which graze and excrete $([19,88,100]$ and Vollenweider. Patalas, personal communication). However, Oviatt and Nixon [112] could not find an influence of introduced clams. Benthic organisms, caught sometimes in bottom-near traps (e.g. Lake Erie experiments 1978 [12, 30, 31, 43, 55, 88, 112, 117 , 167]), are thought to alter the trapped material because of feeding on detritus and respiration. Collection and removal of these colonizing animals after trap retrieval $[12,19,43,88]$ does not necessarily solve the problem.

Recently, some investigators have put chemicals into traps for various reasons, but there are hardly any comparisons with parallel unpreserved traps. Rigler et al. [131] and Kirchner [84] added sodium chloride ( $\mathrm{NaCl}$ ) to build up density gradients, as mentioned previously. Rigler et al. [131] moreover added Lugol to preserve collected zooplankton, while Ferrante and Parker [34] used formalin. Lastein [88] used iodine solution $\left(\mathrm{I}_{2}\right)$ to avoid mineralization but found no difference from a parallel trap without chemicals. Also Hartwig [55] reported no significant difference between traps with and without mercurium chloride $\left(\mathrm{HgCl}_{2}\right)$, even though the bacteria had not been killed. For the same reason, Matsuyama [93] added phenol, and Lawacz [90] and Kajak (in Edmondson and Winberg [28]) used formalin and chloroform in reference traps, but the authors give no results on the comparison. Smetacek et al. [143] and Zeitschel et al. [180] also used chloroform as a preservative. referring to Hendrikson [58], "who found that Chloroform ... tends to convert Chlorophyll to pheopigments but prevents further breakdown that inevitably takes place if no preservative is used". However, Smetacek (l.c.) reported that zooplankton migrated 
into the traps and were killed by the poison, thus altering the sedimentation rates. Honjo [62] and Spencer et al. [145] finally added sodium azide $\left(\mathrm{NaN}_{3}\right)$, but they found that the parallel trap without bactericide caught more material $(6.90 \mathrm{~g}=61.3$ $\left.\mathrm{mg} / \mathrm{m}^{2} \cdot \mathrm{d}\right)$ than the preservative-treated $\operatorname{trap}\left(3.45 \mathrm{~g}=30.7 \mathrm{mg} / \mathrm{m}^{2} \cdot \mathrm{d}\right)$. Our own experiments showed that different bactericides, such as mercurium chloride $\left(\mathrm{HgCl}_{2}\right)$, mercurium iodide $\left(\mathrm{HgI}_{2}\right)$, Thymol or Merphen, either interfered in chemical analyses or even created the opposite effect by enabling some specialized bacteria to grow as if on a culture-medium (Bloesch, unpublished data).

In our opinion, there is an obvious lack of information in this matter because of inadequate resuits, and therefore discussion is limited to theoretical considerations. This problem of artificial mineralization in traps is not yet solved and urgently needs further investigation. However, we can limit this negative effect if we make the exposure time as short as possible. Usually, traps are exchanged at weekly or biweekly intervals. The exposure time should definitely not exceed 3 weeks, if questions of balances, settling fluxes of particulate organic matter and sediment accumulation rates are considered. Results on organic materials obtained from traps left 1 month or longer are questionable. Long-term exposures have been made (e.g.) by Reissinger [124]: 23/4-6 years, Rossolimo [132]: 1 year, Heim [57]: 1 year, Scott and Miner [139]: 10.8-60 months, Sugawara [151]: 21-67 days, Chalupa and Vorderwinklerova [17]: 27-188 days, usually 2 months, Matsuyama [93]: 3 months, Håkanson [48]: 1-2 months. Time may play a minor role if pollen grains (Davis [21]: 1 year) or plankton fossils (Deevey et al. [26]: 67-268 days) are collected. Special studies of sinking velocities of phytoplankton or zooplankton require short collecting periods of $1-3$ days $[46,73,127,128,131]$.

In contrast, Kajak (in Edmondson and Winberg [28]), based on his and other East European authors' (Rossolimo [132], Chalupa and Vorderwinklerova [17]) experiences, comes to the conclusion that "there was no substantial influence of the containers' time of exposure on their contents of organic matter". However, if we look at Rossolimo's table 1 (p. 8), where a year's catch is compared with the sum of monthly short-term measurements, Kajak's cited loss of organic matter of $3.3 \%$ (p.23) turns out to be $21.6 \%$. Further, the losses of dry weight and inorganic matter are reported in this table to be $15.7 \%$ and $8.4 \%$, respectively.

Johnson and Brinkhurst [74], using a funnel-shaped trap, found "the sum of organic matter in separate collection on 6 consecutive days ... yielded an estimate of the deposition rate of $0.75 \mathrm{~g} \mathrm{~m}^{-2} \mathrm{day}^{-1}$, whereas the cumulative 6-day collection gave a rate of $0.52 \mathrm{~g} \mathrm{~m}^{-2} \mathrm{day}^{-1}$. The deposition rate of inorganic material was identical, 1.30 $\mathrm{g} \mathrm{m}^{-2}$ day $^{-1}$, from the 6-day collection and the sum of daily collections." Based on other experiments, these authors estimated the loss of energy through microbial metabolism in the detained sediment to be $15-25 \%$ within 1 week and therefore used a correction factor of 1.2 to calculate accurate sedimentation rates $\left(\mathrm{g} \mathrm{m}^{-2} \mathrm{day}^{-1}\right)$ based on a weekly exposure period.

Steele and Baird [147] exposed jars for a 12-day period and compared the catch with other jars which were exchanged every $2-3$ days during the same period. They got long-term vs. $\Sigma$ short-term ratios of 0.62 to 0.79 , av. 0.70 , for chlorophyll $a$, 0.57 to 1.06 , av. 0.81 , for particulate organic carbon, and 
0.40 to 1.05 , av. 0.72 , for ash weights,

and concluded that "any decrease over the 12 -day periods is probably due to losses rather than to decomposition of the organic material".

Since Steele and Baird [147], as well as Johnson and Brinkhurst [74], used badly designed traps, variable undertrapping effects which differed from day to day because of changing currents may have interfered with and diminished their longterm vs. $\Sigma$ short-term ratios.

Bombowna's [12] results most possibly are linked with even more serious inadequacies. She compared monthly period catches with catches from April to November/ December (211-248 days) over 3 years (1957-9) at the deepest site of a shallow reservoir. We calculated her long-term vs. $\Sigma$ short-term ratios from her tables 17 and 18 to be

$0.40-1.67$ for volume,

$0.59-1.16$ for dry weight,

$0.47-1.31$ for organic material (loss on ignition) and

$0.35-1.01$ for total nitrogen.

The fact that long-term catches can exceed the sum of short-term catches can only be explained by errors in analysis (e.g. insufficient ignition temperatures $\left(400^{\circ} \mathrm{C}\right.$ instead of $550^{\circ} \mathrm{C}$ ) or by attached growth on the long-term traps.

Dörrstein [27], using cylinders, compared 5 summed catches of 3-4 day's periods with a total catch of 16 days (3-19 July 1976) in the alpine Lake Piburg, Austria, and found long-term vs. $\Sigma$ short-term ratios of

11.05 to $11.51 \mathrm{~g} \mathrm{~m}^{-2}=0.96$ for dry weight,

5.06 to $5.38 \mathrm{~g} \mathrm{~m}^{-2}=0.94$ for particulate carbon,

578 to $624 \mathrm{mg} \mathrm{m}^{-2}=0.92$ for particulate nitrogen and

41.8 to $45.6 \mathrm{mg} \mathrm{m}^{-2}=0.91$ for particulate phosphorus.

He concluded that during the time of maximum sedimentation rates (summer) the mineralization effect within 2 weeks is less than 10\%. Psenner [195] confirmed this conclusion with his interesting finding that the development of the mean bacterial biomass in the lake water followed the $\mathrm{N}$ and $\mathrm{P}$ sedimentation with a delay of about 2 weeks. He (Psenner) concluded that during this period bacterial growth was inhibited as a result of the rapid autolytic decomposition which takes place while the particulate material is settling.

Our investigations in Lake Erie (table 7) showed that the loss of material is within $6-13 \%$ in 1 week, comparing a 1-week exposure period (A) with a 2-week period (B) over a 2-month period. Thus an assumed underestimation at a biweekly sampling basis is in the order of $10 \%$. If the exposure time is extended to 3 months (C), however, the losses are significantly higher and falsify the sedimentation rates in an unacceptable way.

Comparing shorter time periods, we can see further that the different long-term vs. $\Sigma$ short-term ratios can vary considerably and not even simultaneously with time:

$\begin{array}{lllllr} & & \text { D.W. } & \text { POC } & \text { PN } & \text { PP } \\ \text { 12.7.-28.7. } & 16 \text { days vs. } \Sigma 6 \text { days }+10 \text { days } & 0.91 & 0.74 & 0.67 & 0.94 \\ 28.7 .-10.8 . & 13 \text { days vs. } \Sigma 4 \text { days }+9 \text { days } & 0.89 & 0.90 & 0.94 & 0.95 \\ 10.8 .-21.8 . & 11 \text { days vs. } \Sigma 5 \text { days }+6 \text { days } & 0.94 & 0.93 & 0.96 & 0.79 \\ 21.8 .-6.9 . & 16 \text { days vs. } \Sigma 9 \text { days }+7 \text { days } & 0.88 & 0.76 & 0.78 & 0.85\end{array}$


Table 7. Influence of exposure time upon sedimentation rates. Lake Erie, offshore station, depth $37 \mathrm{~m}$. D.W.. $\mathrm{g} \mathrm{m}^{-2} \mathrm{~d}^{-1}$. POC, $\mathrm{N}, \mathrm{P}, \mathrm{mg} \mathrm{m}^{-2} \mathrm{~d}^{-1}$.

Tabelle 7. Einfluss der Expositionszeit auf die Sedimentationsraten. Erie-See, uferferne Stelie, Tiefe $37 \mathrm{~m}$. Trockengewicht, $\mathrm{g} \mathrm{m}^{-2} \mathrm{~d}^{-1}$. Partikulärer organischer $C, \mathrm{~N}, \mathrm{P}, \mathrm{mg} \mathrm{m}^{-2} \mathrm{~d}^{-1}$.

\begin{tabular}{|c|c|c|c|c|c|c|}
\hline & Time period 1978 & Days & D.W. & POC & $\mathrm{N}$ & $\mathrm{P}$ \\
\hline & 12.7.-18.7. & 6 & 5.1 & 345 & 59 & 6.6 \\
\hline & $18.7 .-28.7$. & 10 & 5.9 & 488 & 75 & 6.3 \\
\hline & $28.7-1.8$ & 4 & 9.2 & 424 & 54 & 8.2 \\
\hline & $1.8 .-10.8$ & 9 & 6.45 & 356 & 47 & 6.9 \\
\hline & 10.8.-15. 8. & 5 & 8.0 & 455 & 59 & 9.7 \\
\hline & $15.8 .-21.8$ & 6 & 9.3 & 424 & 54 & 9.2 \\
\hline & $21.8 .-30.8$. & 9 & 6.8 & 358 & 45 & 7.3 \\
\hline & $30.8 .-6.9$. & 7 & 7.5 & 413 & 54 & 7.9 \\
\hline & 6.9.-20. 9 & 14 & 8.9 & 427 & 52 & 8.4 \\
\hline & $20.9 .-10.10$ & 20 & 9.8 & 355 & 44 & 8.7 \\
\hline \multirow[t]{7}{*}{ A } & $12.7 .-10.10$ & $\Sigma 90$ & $\Sigma 715$ & $\Sigma 35,860$ & $\Sigma 4,753$ & $\Sigma 713.8$ \\
\hline & $12.7 .-28.7$ & 16 & 5.1 & 322 & 46 & 6.0 \\
\hline & $28.7-10.8$ & 13 & 6.5 & 339 & 46 & 6.9 \\
\hline & $10.8 .-21.8$ & 11 & 8.2 & 406 & 54 & 7.4 \\
\hline & $21.8-6.9$. & 16 & 6.25 & 289 & 38 & 6,4 \\
\hline & $6.9 .-20.9$ & 14 & 8.4 & 403 & 52 & 8.0 \\
\hline & $20.9--10.10$ & 20 & 9.8 & 355 & 44 & 8.7 \\
\hline \multirow[t]{3}{*}{ B } & $12.7,-10.10$ & $\Sigma 90$ & $\Sigma 670$ & $\Sigma 31.391$ & $\Sigma 4.144$ & $\Sigma 655.5$ \\
\hline & $B$ in $\%$ of $A$ & & $94 \%$ & $88 \%$ & $87 \%$ & $92 \%$ \\
\hline & 12.7.-10.10 & 90 & 6.9 & 236 & 35 & 5.1 \\
\hline \multirow[t]{3}{*}{ C } & $12.7 .-10.10$ & $\Sigma 90$ & $\sum 620$ & $\Sigma 21,205$ & $\Sigma 3.167$ & $\Sigma 456,0$ \\
\hline & $\mathrm{C}$ in $\%$ of $\mathrm{A}$ & & $87 \%$ & $59 \%$ & $67 \%$ & $64 \%$ \\
\hline & $C$ in $\%$ of $B$ & & $93 \%$ & $68 \%$ & $76 \%$ & $70 \%$ \\
\hline
\end{tabular}

As sedimentation as well as mineralization of the settling material changes during the season and from lake to lake, no real generalization about losses is possible. However, it is to be expected, the losses due to mineralization decrease with time. A probable exposure time of 1 day is not practical in many cases because of inadequate catches or other limitations. However, if we consider the fast mineralization rates of phytoplankton [184,185] as well as of zooplankton [190-192], with a phosphorus release of $\geq 70 \%$ within 1 day, and moreover assume mean sinking velocities of $\geq 1$ to $4 \mathrm{~m} /$ day in the epilimnetic layer of a lake, it is likely that a large portion of the dead cells have already lost most of their phosphorus before they reach a trap set at the lower boundary of the epilimnion. Thus only the more refractory components (partly nitrogen, organic carbon) will be collected in the hypolimnetic layers and affected by bacterial breakdown. If the traps in the hypolimnion are exchanged every 2 weeks bacterial breakdown will not influence the sedimentation rates unduly especially since the rather low temperatures below the thermocline do not favour excess bacterial growth. The question of which cells are actually decomposed within the trap during exposure time or which have reached the trap already having lost phosphorus or nitrogen components has never been investigated seriously in an experiment to the present. 


\section{Trap moorings}

Many different mooring systems have been used but the usual mooring system is shown schematically in figure 7. It consists of an anchor weight on the lake bottom and a rope or a cable stretched by a subsurface buoy which is marked by a smaller buoy. In the case of a small lake a rope may lead to the shore from the subsurface float. The more turbulent the water, the deeper the subsurface float must lie. Wind induced waves cause oscillatory motions in the float which can then be transferred down the line and cause resuspension of material in the trap. Surface buoys lead to significant losses from traps by transferring the motion caused by waves down the mooring line to the subsurface float and traps (about 70-98\% [117]). The trap is fixed

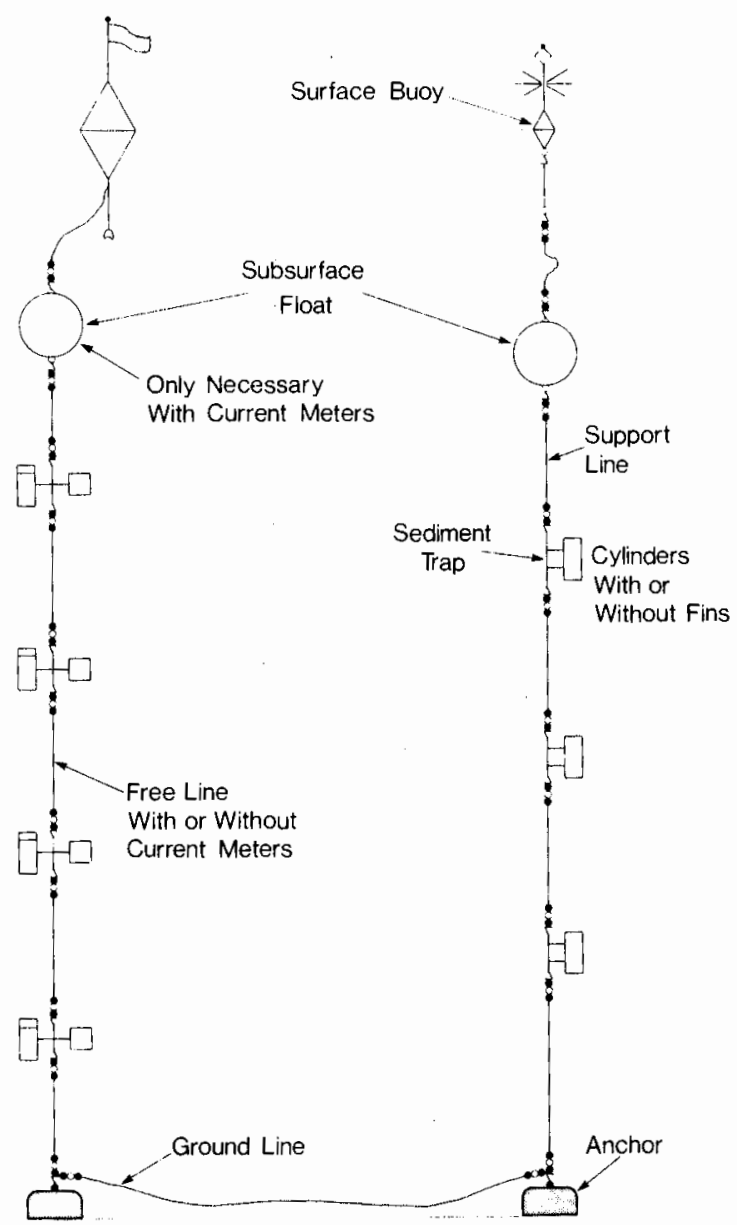

Figure 7. Typical mooring system (after Zeitzschel et al. [180] redrawn). The free line with current meters is optional.

Abb. 7. Typische Aufhängevorrichtung (umgezeichnet aus Zeitzschel et al. [180]). Die freie Leine (links) mit oder ohne Strömungsmessgerăten ist fak ultativ. 
at any desired depth of the lake either in a single fitting or in a frame carrying one or more replicates (fig. 8).

The attachment of the traps to the vertical cable can be very simple if there is little horizontal movement of the surrounding water. However, in high flow situations the traps must be attached so that they can rotate about the cable. This should be done by attaching a fin to trap-holder frames so that the traps are upstream of the suspending cable and the fin downstream. If the frame holding the traps cannot rotate or does not have a fin, a strong current flowing past the unit could cause it to vibrate and thus resuspend the collected material.

After several weeks exposure in eutrophic water the cable will likely have a significant amount of attached growth. This can be minimized by carefully rubbing this material off the cables when the traps are changed. If this is not done the material may detach from the cable in situ and settle into the traps.

The bottom traps should not be too close to the mud surface (i.e. about $1-3 \mathrm{~m}$ above) because of possible trapping of resuspended lake bottom deposits. Resuspen-

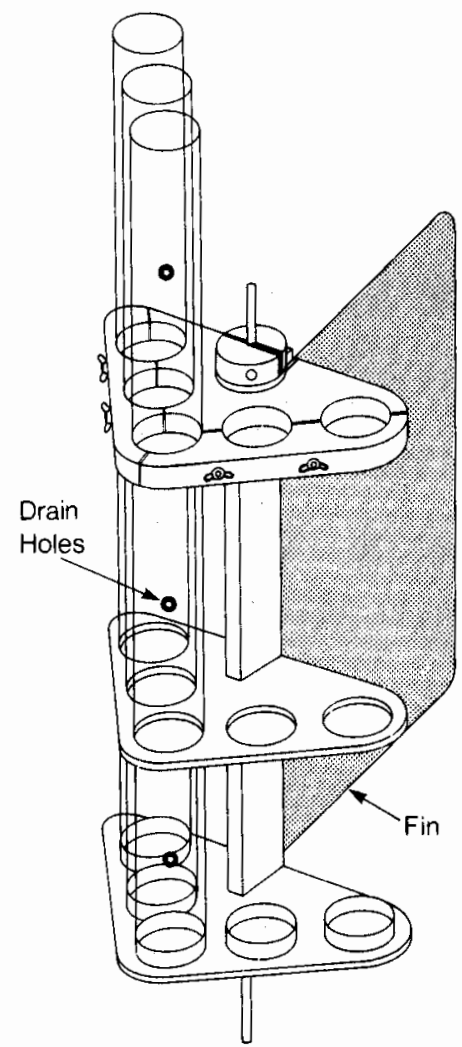

Figure 8. Example of a sediment trap apparatus with 5 replicated traps. This trap was used during our Lake Erie investigations in summer 1978. (Design of M.N. Charlton, F. Roy and N.M. Burns.) Abb. 8. Beispiel eines Gestells mit 5 Parallelfallen. Dieser Sedimentierapparat wurde während unserer Erie-See-Untersuchungen im Sommer 1978 eingesetzt. (Pläne und Konstruktion von M. N. Charlton, F. Roy und N.M. Burns.) 
sion itself can be quantified by a vertical series of traps at different distances off the bottom [178].

Parallel traps are necessary if methodological aspects are investigated and if the traps have different lengths they should have their openings at the same level so as to allow similar flow patterns. Different mooring sites may provide interesting insights to overall lake sedimentation processes $([17,139]$ and Bloesch et al., in preparation).

A very interesting proposal for the use of a free-drifting sediment trap was recently made by Staresinic et al. [146] and Zeitschel et al. [180] but this floating mooring system can only be applied in oceans or very large lakes, e.g., the Laurentian Great Lakes. This system needs a low traffic area and continuous tracking.

When the traps are lowered they will fill with surface water which will be the warmest and least dense water in the lake. This water will be displaced by the water surrounding the trap, as the traps are lowered into deeper, colder water. There is absolutely no reason to fill traps with distilled water before exposure [75]. Only for very short experiments (hours) would it make sense to prefill the traps with lake water from the same depth where the traps are exposed.

\section{Sampling material from sediment traps}

If no reference trap is used (see p. 37) then it is important to draw off the water from the trap with relatively little shaking. On retrieval, the trap should be first carefully examined to see whether the material at the bottom was disturbed as the trap was lifted. If this was the case then all the water in the trap must be considered as sample and poured into a large jug where it would be mixed well and then subsampled. If there was no resuspension on retrieval, some of the supernatant liquid can be siphoned off or drained off through a series of drain holes in the side of the cylinder. The drain hole closest to the water surface should be used so as to avoid high pressures and strong jets of water from the side of the cylinder. If the currents inside the trap associated with the draining water were strong they could cause resuspension of the settled material. Once the supernatant water has been removed the remaining sample can be removed through a hole in the bottom of the trap. Subsampling of the collected sample should be done with care because Davis [21], for example. has reported that subsampling of trap samples for pollen analysis can be quite inaccurate.

\section{Summary and recommendations}

Based on theoretical considerations (chap.2), evidence from in vitro and in situ experiments (chap.3) together with our own practical experience (chap.4), we recommend that the appropriate trap for lake studies is a simple cylinder made of transparent plastic with a diameter varying between 5 and $20 \mathrm{~cm}$ and having an aspect ratio (height:diameter) of greater than 5 for calm water situations and greater than 10 for turbulent situations (large lakes and oceans). Choice of a cylindrical trap of appropriate aspect ratio avoids overtrapping as well as undertrapping of particulate material. We moreover are convinced that all kinds of accessories (collars, 
lattices, baffles, lids, reference chambers, as outlined in chap.4) are not necessary and do not improve sediment trap efficiency.

In regard to the moorings we recommend the smallest possible surface markers and that the subsurface float be set below the depth of wave induced motion. Vibratory movement of sediment trap fixtures in strong currents can be diminished by attaching a stabilizing fin to the sediment trap frame and allowing it to rotate about the cable. Sediment trap samples which show evidence of resuspension during the retrieval process should be mixed well and then subsampled. Undisturbed samples can have the supernatant water drawn off before sampling.

Despite opinions to the contrary (chap. 1), comparison of settling fluxes as measured by sediment traps with those measured by different methods $[9,117,122,131]$ have shown that sedimentation traps are a useful tool to measure downward settling fluxes. Though poor comparative results with traps are reported, these are relatively rare [26].

There are processes which affect calculated settling fluxes but which have nothing to do with the efficiency or the design of sediment traps. These interfering effects are resuspension of bottom deposits, increasing the catches, and artificial mineralization within the trap, decreasing the catches due to losses of organic material. Resuspension, occurring mainly in shallow, wind exposed water bodies and near bottom, has been recognized in many studies, and even measured [42, 43, 110, 130, 178], and may be corrected for $[19,29,40,75,88,100,141]$. The continuing debate in the literature about mineralization effects in sediment traps shows that this problem has not been solved. The question of whether to use preservatives and which ones, is not fully answered and more investigations are needed. However, this problem can be minimized by keeping the trap exposure time as short as possible.

\section{ACKNOWLEDGMENT}

We would like to express our thanks to $M$. A. Donelan for his suggestions and help with hydrodynamic considerations.

\section{ZUSAMMENFASSUNG}

Eine kritische Ubersicht über die Sedimentfallentechnik

Diese Arbeit, angeregt durch die Experimente von Gardner [36] und Hargrave und Burns [51], entstand aus dem Bestreben heraus, einerseits einen umfassenden Uberblick uber die bestehende Sedimentfallenliteratur (180 Titel, siehe Tab.4 und Literaturverzeichnis I) zu vermitteln, anderseits die durch eine Vielfalt von verschiedenen Fallentypen (Abb.1) entstandene Konfusion bezuglich korrekter Sedimentationsmessungen mit Sedimentfallen zu klären. Eine Vereinheitlichung der Fallen wurde die Vergleichbarkeit von Resultaten wesentlich verbessern. In Kapitel / werden kontroverse Auffassungen prominenter Autoren dargestellt. Wir möchten dazu bemerken, dass wir hier die Sedimentfallen nur als Instrumente zur Messung des Sinkfluxes von Partikeln betrachten und dass wir auf Störungen wie Trichtereffekt oder Resuspension von Bodensedimenten nicht năher eingehen. Jedenfalls erweisen sich Sedimentfallen in den meisten Fällen als ein taugliches Mittel zur Messung von Sedimentationsraten, wie Vergleiche mit anderen Methoden gezeigt haben $[9,117,122,131]$.

Aufgrund theoretischer Uberlegungen (Kap.2) und experimenteller Erfahrungen (Kap.3) empfehlen wir für limnologische Untersuchungen ais «beste" Sedimentfalle einen einfachen Zylinder aus PVC oder Plexiglas mit einem Durchmesser von 5 bis $20 \mathrm{~cm}$ und einem Verhaltnis Höhe:Durchmesser (aspect ratio) von mindestens 5 für kleine Seen und mindestens 10 für turbulentere Gewåsser. Nur eine richtig 
proportionierte zylinderförmige Faalle erfüllt zwei essentielle Bedingungen, welche sowohl in ruhigem als auch in turbulentem Wasser eine Auffangeffizienz um 100\% gewährleisten (siehe Kapitel 2): 1. Die Partikelkonzentration muss bei ruhigen und turbulenten Verhältnissen innerhalb und ausserhalb der Falle gleich sein. 2. Das auf den Boden der Falle sedimentierte Material darf unter keinen Umständen durch Turbulenzen wiederaufgewirbelt werden, ansonst Verluste auftreten (vgl. Tab.2 und 3, Abb.4). Trichter und flache Gerasse sammeln infolge solcher Resuspension zu wenig. Flaschen und ähnliche enghalsige Fallen sammeln zu viel Material (Abb.3), wenn die Öffnung als Auffangfàche genommen wird. (Falls die Bodenfläche berücksichtigt wird, kommt man zu ähnlichen Resultaten wie mit einem Zylinder [51].) In Abb. 2 sind die möglichen Wege sedimentierender Partikel schematisch dargestellt: in turbulenten Verhältnissen dürfen sie nicht mit denjenigen von Regentropfen oder Schneeflocken verglichen werden. weil die Differenz zwischen der vertikalen Sinkgeschwindigkeit der Partikel und der horizontalen Geschwindigkeit des umgebenden Mediums im Wasser 1-6 Grössenordnungen grösser ist als in Luft (Tab. 1).

Die in Kapitel 2 entwickelte Theorie und die daraus abgeleitete Empfehlung basieren auf der Erkenntnis, dass Turbulenzen keinen Einfluss auf die Sinkgeschwindigkeit kleiner Partikel $(<250 \mu \mathrm{m})$ haben. weil ihre Reynolds-Zahl Re<0,5 ist [187, 199]. (Dagegen kann sehr wohl die Partikelverteilung bzw. der Partikelflux durch Turbulenz verändert werden.) Für die relativ seltenen grösseren Partikel $(\mathrm{Re}>0,5)$ trifft dies nicht mehr genau zu [182, 189, 194, 199]. weshalb es von grösstem Nutzen ist, die ungefähre Reynolds-Zahl der von der Sedimentfalle gesanmelten Partikel zu kennen. (Immerhin kann für Re $>0,5$ eine Korrektur vorgenommen werden, siehe S.28.)

Die aus der physikalischen Theorie (Kap.2) hergeleiteten Erfordernisse werden durch Labor- und Insitu-Experimente mit verschiedenen Fallentypen und -grössen bestätigt (Kapitel 3, siehe Tab.2 und [2!. 36, 51, 74, 84, 117, 147, 168, 170, 174, 178]). Parallelfallen (Abb.8) ergeben meistens kleinere Differenzen als $10 \%$ (siehe Tab. 5 und $[27,82,171]$ ).

In Kapitel 4 werden praktische Aspekte der Sedimentfallentechnik diskutiert. Verschiedene Gründe sprechen gegen die Verwendung von gelochten Abdeckhauben (Tauber-Falle [156]). Gittern, Einsätzen zur Verminderung von Turbulenzen (Abb.5), Schliessmechanismen bzw. Deckel und Referenzkammern (Abb.6). Solche Vorrichtungen nützen entweder nichts und stören deshalb nur [Einsätze (Tab.6). Deckel], oder sie bringen neue Probleme mit sich, welche die Messgenauigkcit eher verschlechtern als verbessern (Abdeckhauben. Gitter, Referenzkammern). Ein nach wie vor ungelöstes Problem stellt hingegen die künstliche Mineralisierung organischen Materials innerhalb der Falle dar. (Inwieweit gelegentlich gefangene Benthosorganismen die Sedimentationsmessungen stören, ist ebenfalls nicht bekannt.) Zur Vermeidung des unerwünschten Abbaueffektes werden in jüngster Zeit mehr und mehr verschiedene Konservierungsmittel bzw. Bakterizide (z. B, Formol. Chloroform, $\mathrm{HgCl}_{2}$, Lugol, u.a.) angewandt. Solche Mittel können jedoch auch neue Fehler einschleppen (Abtöten von Zooplankton. Nährboden für spezialisierte Bakterien). Bis experimentelle Vergleiche mit behandelten und unbehandelten Sedimentfallen vorliegen. welche die Tauglichkeit von Bakteriziden beweisen würden, ist im Gebrauch solcher Mittel grosse Vorsicht am Plak. Vorläufig kann dieses Problem durch möglichst kurze Expositionszeit (1-2 Wochen) minimiert werden, wie Vergleiche von Kurzzeit-mit Langzeitexpositionen gezeigt haben (Tab. 7). Schli sslich sei auch noch darauf hingewiesen. dass korrekt gemessene Sedimentationsraten nicht zuletzt auch von kleinen Details abhängen, nämlich von der Art der Aufhängevorrichtung $(A b b, 7)$, der Fixierung der Falien am Seil oder Kabel und einer sorgfaltigen Probenentnahme aus den Gefässen.

\section{RÉSUMÉ}

Une analyse critique de la technique des trappes à sédiments

Celte publication, inspirée par les expériences de Gardner [36] et de Hargrave et Burns [51], résulte de l'intention. d'une part de donner un sommaire complet de la littérature sur les trappes à sédiments (180 titres. voir tabl.4 et références I). d'autre part de clarifier la confusion à l'égard des mesurages corrects de la sédimentation par des trappes à sédiments; cette confusion provenant d'une grande diversité dans les difrerents types de trappes (fig. 1). Une standardisation des trappes améliorerait nettement la comparabilité des résultats. Dans le chapilre /, des opinions controversées d'auteurs éminents sont énumérées. Nous aimerions faire remarquer que nous ne considérons ici les trappes que comme instruments de mesure de la sédimentation des particules. et que nous n'approfondissons pas la question des perturbations comme 
par exemple "l'effet d'entonnoir» ou la resuspension des sédiments du fond du lac. En tout cas, les trappes à sédiments s'avèrent être des moyens presque toujours propres à mesurer la sédimentation, comme ont démontré les comparaisons avec d'autres méthodes $[9,117,122,131]$.

Sur la base des considérations théoriques (chap.2) et des expériences pratiques (chap.3) nous pouvons recommander comme "meilleure trappe», pour les explorations limnologiques, un simple cylindre fabriqué en PVC ou verre plexi d'un diamètre de $5-20 \mathrm{~cm}$ et d'une proportion hauteur: diamètre (aspect ratio) d'au moins 5 pour les petits lacs et d'au moins 10 pour les eaux plus turbulentes. Seulement une trappe cylindrique correctement proportionnée satisfait aux deux conditions essentielles qui permettent une efficacité de prise d'environ $100 \%$ aussi bien dans l'eau calme que dans l'eau turbulente (chapitre 2): 1. que la concentration des particules soit égale à l'intérieur et à l'extérieur de la trappe dans les conditions cálmes et turbulentes; 2 . que le matériel sédimenté au fond de la trappe ne soit jamais soulevé par des turbulences. sinon il y aura des pertes (tabl. 2 et 3, fig. 4). Des entonnoirs et des récipients plats ramassent trop peu de matériel (à cause des resuspensions), des bouteilles et des récipients similaires à col étroit ramassent trop de matériel (fig. 3), si l'ouverture est considérée comme face de ramassage. (Mais si on considère la face du fond, on obtient des résultats similaires à ceux d'un cylindre [51].) Dans la figure 2 les passages possibles de particules sédimentantes sont présentés schématiquement: dans des conditions turbulentes, ils ne doivent pas être comparés à ceux des gouttes de pluie ou de flocons de neige. parce que la différence entre la vitesse verticale de sédimentation des particules et la vitesse horizontale du milieu environnant est 10 à $10^{6}$ fois plus grande dans l'eau que dans l'air (tabl. 1).

La théorie développée dans le chapitre 2 et la recommandation qui en découle se fondent sur le fait que la turbulence n'a pas d'influence sur la vitesse de sédimentation des petites particules $(<250 \mu \mathrm{m})$, parce que leur nombre Reynolds Re est $<0.5[187,199]$. (En revanche, la turbulence peut changer la distribution des particules. respectivement le flux des particules.) Pour les particules plus grandes $(R e>0.5)$ relativement rares, cela n'est plus tout à fait juste $[182,189,194.199]$, et c'est pourquoi il est très utile de connaitre le nombre Reynolds approximatif des particules ramassées par la trappe. (Toutefois il existe une correction pour $\mathrm{Re}>0,5$, voir p. 28.)

Les exigences dérivées de la théorie physique (chap.2) sont confirmées par des expériences de laboratoires et in situ effectuées avec des différents types et formats de trappes (chapitre 3, voir aussi tabl. 2 et $[21,36,51,74,84,117,147,168,170,174,178])$. Des trappes parailèles (fig. 8) produisent le plus souvent des différences inférieures à $10 \%$ (tabl. 5 et $[27,82.171]$ ).

Dans le chapitre 4 des aspects pratiques de la technique des trappes à sédiments sont discutés. Des raisons variées s'opposent à l'usage des chapes perforées (la trappe de Tauber [156]), des grilles, des éléments pour éviter les turbulences (fig. 5), des plaques et des «chambres de référence» (fig.6). De tels mécanismes sont ou inutiles et gênants [élements (tabl.6) et couvercles]. ou causent de nouveaux problèmes qui détériorent plus qu'ils n'améliorent la précision des mesurages (chapes, grilles, «chambres de référence»). Au contraire, un problème qui reste toujours à résoudre est la minéralisation artificielle du matériel organique au fond des trappes. (Jusqu'à quel point des organismes benthiques capturés occasionnellement influencent les mesures de sédimentation est aussi inconnu.) Pour éviter l'effet indésirable de la dégradation, on a commencé récemment et de plus en plus à utiliser des agents de conservation, c'est-à-dire des bactéricides (par exemple le formol, chloroforme, $\mathrm{HgCl}_{2}$, lugol, etc.). Mais de telles substances peuvent aussi causer de nouvelles erreurs (mort du zooplancton, milieu de culture pour des bactéries spécialisées). Tant que des comparaisons expérimentales avec des trappes traitées et non traitées. qui prouveront l'effet des bactéricides, ne soient faites, il est prudent d'user de ces produits avec grande précaution. Pour le moment, ce problème peut être minimisé par un temps d'exposition le plus court possible (1-2 semaines) ce qui a été prouvé par des comparaisons entre des expositions à temps courts et celles à long terme (tabl.7). Finalement, nous montrons que la mesure correcte de la sédimentation dépend aussi de petits details, comme le mode de suspension (fig.7), la fixation des récipients à la corde ou au câble. et il faut aussi ôter les échantillons hors des récipients avec précaution.

\section{REFERENCES 1: Sediment trap literature}

This list does not claim to be complete, though it has been put together most carefully. Any additional contributions of references in favour to the authors are highly appreciated.

1 Anderson, R. Y.: Short-term sedimentation response in lakes in western United States as measured by remote sampling. Limnol. Oceanogr. 22, 423-433 (1977). 
2 Ansell, A. D.: Sedimentation of organic detritus in Lochs Etive and Creran, Argyll, Scotland. Mar. Geol. 27, 263-272 (1974).

3 Axelsson, V.: Rapaälven, dess delta samt sedimentationen i Laitaure. Ett preliminärt meddelande. Ymer 75/1, 52-59(1955).

4 Axelsson, V., and Hăkanson, L.: The relation between mercury distribution and sedimentological environment in Lake Ekoln, part 4. Deposition of sediment and mercury in 1971 and 1972. Univ. Uppsala UNGI Rapp. 35, 42 p. (1975).

5 Bachofen, R.: Stofthaushalt und Sedimentation im Baldegger- und Hallwilersee. Ph.D. thesis, Univ. Zürich, 118 p. (1960).

6 Baseom, W.: Instruments for studying ocean pollution. J. Envir. Engin. Div., ASCE 103, 1-8 (1977).

7 Berger, W.H. and Soutar, A.: Planktonic foraminifera: Field experiment on production rate. Science 156, 1495-1497 (1967).

8 Bloesch, J.: Messung der Sedimentation in verschiedenen Tiefenstufen des Vierwaldstättersees (Horwer Bucht) mit besonderer Berücksichtigung des Phosphors. M.Sc. thesis. Fed. Polytech. Inst., Zürich, 103 p. (1967).

9 Bloesch, J.: Sedimentation und Phosphorhaushalt im Vierwaldstättersee (Horwer Bucht) und im Rotsee. Schweiz. Z. Hydrol. 36, 71-186 (1974).

10 Bloesch, J.: Sedimentation rates and sediment cores in two Swiss lakes of different trophic state. In: Golterman. H. L. (ed.): Interactions between Sediments and Freshwater, p. 65-71 (1977). Proc. Int. Symp. Amsterdam, 6-10 September 1976.

11 Bloesch, J., Stadelmann, P., and Bührer. H.: Primary production, mineralization, and sedimentation in the euphotic zone of two Swiss lakes. Limnol. Oceanogr. 22, 511-526 (1977).

12 Bombowna, M.: Sedimentieren von Sinkstoffen im Staubecken Goczalkowice. Acta Hydrobiol. 4. $69-118$ ( I962).

13 Braidech, T., Gehring, P.. and Kleveno, C.: Biological studies related to oxygen depletion and nutrient regeneration processes in the Lake Erie Central Basin. In: Burns, N.M., and Ross, C., Project Hypo: An intensive study of the Lake Erie Centra! Basin hypolimnion and related surface water phenomena. CCIW, Paper No.6 and US Envir. Prot. Agency, Tech. Rep., TS-05-71-208-24. February 1972, p.51-70 (1972).

14 Brunskill, G.J.: Fayetteville Greenlake, New York. Il. Precipitation and sedimentation of calcite in a meromictic lake with laminated sediments. Limnol, Oceanogr. 14, 830-847 (1969).

15 Burns, N.M.: Factors influencing the design of sediment traps, unpublished manuscript, $20 \mathrm{p}$. (1977).

16 Campbell, P.: Descriptive limnology of Lake 120, a meromictic lake on the precambrian shield in north-western Ontario. M.Sc. thesis, Dept. of Zoology, Univ. Manitoba, Winnipeg, Manitoba, Canada, 118 p. (1976), and Data Appendix, 122 p., Call No.C1535.

17 Chalupa, J., and Vorderwinklerova, H.: L.imnological study of the reservoir Sedlice near Zeliv. IV. The investigation of sedimentation processes (in czech., with engl. summary). Sbornik. Sci. Papers from Inst. of Chem. Technol. Prague, Fac. of Technol. of Fuel \& Water 3/2, 167-220 (1959).

18 Chambers, K.C., and Parker, A.: Modified design for lake-seston traps and a simple method for relocating them. Earth Surf. Processes 4, 73 (1979).

19 Charlton, M.N.: Sedimentation: measurements in experimental enclosures. Verh. int. Verein. Limnol. 19, 267-272 (1975).

20 Davies, J. M.: Energy flow through the benthos in a Scottish sea loch. Mar. Biol. 31, 353-362 (1975).

21 Davis, M.B.: Pollen deposition in lakes as measured by sediment traps. Geol. Soc. Am. Bull. 78, 849-858 (1967).

22 Davis, M.B.: Pollen grains in lake sediments: redeposition caused by seasonal water circulation. Science 162, 796-799 (1968).

23 Davis, M. B.: Redeposition of pollen grains in lake sediments. Limnol. Oceanogr. 18, 44-52 (1973).

24 Davis, M.B., and Brubaker, L. B.: Differential sedimentation of pollen grains in lakes. Limnol. Oceanogr. 18, 635-646 (1973).

25 Deevey, E. S.. Jr.: Preliminary account of fossilization of zooplankton in Rogers Lake. Verh. int. Verein. Limnol. 15, 981-992 (1964). 
26 Deevey, E.S.. Hague Vaughan and Deevey, G. B.: Lakes Yaxha and Sacnab, Peten, Guatemala: Planktonic fossils and sediment focussing. In: Golterman, H.L. (ed.): Interactions between Sediments and Freshwater, p. 189-196 (1977). Proc. Int. Symp. Amsterdam, 6-10 September 1976.

27 Dörrstein, D.: Sedimentation im Piburger See (Otztal, Tirol). Ph.D. thesis, Univ. Innsbruck, 118 p. (1977).

28 Edmondson, W.T., and Winberg, G.G.: A manual of methods for the assessment of secondary productivity in freshwater. IBP Handbook, No.17, 358 p. Blackwell Scientific Publications, Oxford. Edinburgh 1971 .

29 Edwards, R.R.C.: Production ecology of two Caribbean marine ecosystems. II. Metabolism and energy flow. Estuar. Coast. Mar. Sci. 1, 319-333 (1973).

30 Eggleton, F.E.: A limnological study of the profundal bottom fauna of certain freshwater lakes. Ecol. Monogr. 1. 231-331 (1931).

31 Emery, K.O., Tracey, Jr., J.I., and Ladd, H.S.: Geology of Bikini and nearby atolls. U.S. Geol. Surv. Prof. Pap. 260-A, 1-265 (1954)

32 Erdtman, G.: Discussion. Proc. 7th Int. Bot. Congr., Stockholm, p. 882-883 (1950).

33 Fehlmann, W., and Minder, L.: Beitrag zum Problem der Sedimentbildung und Besiedlung im Zürichsee. Festschrift für Zschokke, No. 11 (1921).

34 Ferrante, J.G., and Parker, J.I.: Transport of diatom frustules by copepod fecal pellets to the sediments of Lake Michigan. Limnol, Oceanogr. 22, 92-98 (1977).

35 Fuhs, G.: Improved device for the collection of sedimenting matter. Limnol. Occanogr, 18, 989-993 (1973).

36 Gardner, W. D.: Fluxes, dynamics and chemistry of particulates in the ocean. Ph.D. thesis, MIT/ Woods Hole Oceanogr. Inst., 405 p. (1977).

37 Gardner, W.D.: Sediment trap dynamics and calibration. A laboratory evaluation. J. Mar. Res., 38, 17-39 (1980).

38 Gardner, W. D.: Field assessment of sediment traps. J. Mar. Res., 38, 41-52 (1980).

39 Gardner, W.D., Rowe, G.T., Williams, A.J., and Hollister, C.D.: Particle residence time in an oceanic nepheloid layer and total particulate flux. Transactions, EOS, Am. Geophys. Union 58, 410 (1977).

40 Gasith, A.: Tripton sedimentation in eutrophic lakes - simple correction for the resuspended matter. Verh. int. Verein. Limnol. 19, 116-122 (1975),

41 Gessner, F.: Hydrobotanik, vol. 1, p. 403-404. Berlin 1955

42 Glynn, P.W.: Coral growth in upwelling and nonupwelling areas off the Pacific Coast of Panama. J. Mar. Res. 35, 567-585 (1977).

43 Glynn, P.W., and Stewart, R.H.: Distribution of coral reefs in the Pearl Islands (Gulf of Panama) in relation to thermal conditions. Limnol. Oceanogr. 18, 367-379 (1973).

44 Golterman, H.L.: Vertical movement of phosphate in freshwater. In: Griffith, E.J. et al. (eds.); Environmental phosphorus handbook, p. 509-538, Wiley \& Sons, New York 1973.

45 Götzinger, G.: Die Sedimentierung der Lunzer Seen. Verh. K. K. Geol. Reichsanst. N8 (1911).

46 Grim, J.: Versuche zur Ermittlung des Produktionskoeffizienten einiger Planktophyten in einem flachen See. Bioj. Zentralbl. 69, 147-174 (1950).

47 Grim, J.: Vermehrungsleistungen planktischer Algenpopulationen in Gleichgewichtsperioden. Arch. Hydrobiol., suppl, 20, 238-260 (1952),

48 Håkanson, L.: A bottom sediment trap for recent sedimentary deposits. Limnol. Oceanogr. 21, $170-174$ (1976).

49 Håkanson, L.: Sediments as indicators of contamination - Investigations in the four largest Swedish lakes. Naturvardsverkets Limnologiska Undersökning. Report No.92, 159 p. (1977).

50 Hargrave, B. T.: Seasonal changes in oxygen uptake by settled particulate matter and sediments in a marine bay. J. Fish. Res. Bd Can. 35, 1621-1628 (1978).

51 Hargrave, B.T., and Burns, N.M.: Assessment of sediment trap collection efficiency. Limnol, Oceanogr. 24, 1124-1135 (1979).

52 Hargrave, B. T., and McIntyre, A. D.: Metabolism at the benthic boundary. In: McCave, I. N. (ed.): The benthic boundary layer, p. 297-310. Plenum Press, New York, London 1976.

53 Hargrave, B.T. Phillips, G.A., and Taguchi, S.: Sedimentation measurements in Bedford Basin, 1973-1974. Fish. Mar. Serv. Res. Dev. Tech. Rep. 608, 129 p. (1976). 
54 Hargrave, B.T., and Taguchi, S.: Origin of deposited material sedimented in a marine bay. J. Fish. Res. Bd Can. 35, 1604-1613 (1978).

55 Hartwig, E.O.: Nutrient cycling between the water column and a marine sediment. I. Organic Carbon. Mar. Biol. 34. 285-295 (1976).

56 Hayashi. H., Okino, T., and Aoyama, K. A.: The balance of organic matter in a water column in a lake. I. Examinations in to the propriety of the concept of water column, using an artificial water column separated by a vinyl sheet. Japan. J. Limnol. 33, 51-59 (1972) (Japanese, engl. summary).

57 Heim, A.: Der Schlammabsatz am Grund des Vierwaldstättersees. Vjschr. naturf. Ges. Zürich 45. 164-182 (1900).

58 Hendrikson. P.: Auf- und Abbauprozesse partikulärer organischer Substanz anhand von Sestonund Sinkstotfanalysen. Ph.D. thesis. Univ. Kiel. 160 p. (1975).

59 Hogetsu. K.. Kitazawa, Y.. Kurasawa, H.. Shiraishi, Y.. and lchimura. S.: Fundamental studies on the biological production and metabolism of inland waters. mainly of Lake Suwa (Japanese). Suisan Shigen-Kenkyu $I, 41-127$ (1952).

60 Höhne, E.. and Odrich. E.: Sedimentationsraten. Limnologica 4, 313-320 (1966).

61 Honjo. S.: Coccoliths: Production. transportation and sedimentation. Mar. Micropalaeont. 1, 65-79 (1976).

62 Honjo. S.: Sedimentation of material in the Sargasso Sea at a $5.367 \mathrm{~m}$ deep station. J. Mar. Res. 36 , $469.492(1978)$.

63 Honjo. S.. and Connell. J.F.: A large opening sediment trap applicable in deep ocean. To be published as a WHOI Technical Report. 1977. In preparation.

64 Honjo, S.. and Erez. J.: Dissolution rates of $\mathrm{CaCO}_{3}$ in the deep ocean: an in-situ experiment in the North Atlantic Ocean. Earth Planet. Sci. Lett. 40, 287-300 (1978).

65 Honjo. S. and Roman. M.R.: Marine copepod fecal pellets: production, preservation and sedimentation. J. Mar. Res. 36. 45-57 (1978).

66 Hopkins. J.S.: Differential flotation and deposition of coniferous and deciduous tree pollen. Ecology 31. 633-641 (1950).

67 Hoskin. C.M., Burrell, D.C.. and Freitag. G. R.: Suspended sediment dynamics in Queen Inlet. Glacier Bay. Alaska. AGU Abstract. San Francisco. Fall 1975. EOS. Trans. Am. Geophys. Union. $56 / 12,1003(1975)$.

68 Hough. J.L.: Bottom-sampling apparatus. Recent Marine Sed. Symposium. P. D. Trask (ed.). Am. Ass. Petrol. Geol. Bull.. Tulsa. Oklahoma. p.631-664 (1939) (Republ. 1955).

69 Inman. D. L.: Sediment trap studies of suspended material near the surf zone. Scripps Institute of Oceanography. University of California. Quarterly Progress Rept No.2 to Beach Erosion Board, Corps of Engr. (1949) (Contract W-49-055-eng-3).

70 Izeki. K.: In situ measurement of the vertical flux of particles by a newly designed collector. Chem. Ocean. Soc. Dept. Fish., Tohoku University, preprint collection, No.3, p. 18-25 (1976).

71 Ižjurova. A. I: Vzvešennye veščestva i donnye otloženija Klazminskogo Vodochraniliš̌ca. Trudȳ Vsesojuz. Gidrobiol. Obšč. 10, 25-35 (1960).

72 Jakovleva. I.V.: Charakteristika donnych otloženij Borక̌censkogo vodochraniliš̌̌a Gidrologičeskij režim malych vodojemov Kurskoj Oblasti. Trudy Lab. ozerov. AN. SSSR 13, 103-113 (1961).

73 Järnefelt. H.: Öber die Sedimentation des Sestons. Verh. int. Verein. Limnol. 12, 144-158 (1955).

74 Johnson. M.G., and Brinkhurst. R. O.: Benthic community metabolism in Bay of Quinte and Lake Ontario. J. Fish. Res. Bd Can. 28, 1715-1725 (1971).

75 Johnson. D.: Seston and sedimentation in Farmoor Reservoir. Great Britain. In: Golterman, H.L. (ed.): Interactions between Sediments and Freshwater, p.179-182 (1977). Proc. Int. Symp. Amsterdam. 6-10 September 1976.

76 Kajak. Z.: Sedymentacja tryptonu i miarodajnošč jej oceny. Wiadomości Ekologiczne, in press.

77 Kajak. Z.. Hilibricht-llkowska. A.. and Pieczynska, E.: The production processes in several polish lakes. In: Kajak, Z., and Hillbricht-llkowska. A. (eds.): Productivity problems of fresh waters, p. 129-147 (1972). Proc. IBP-UNESCO symp. Kazimierz Dolny, Poland. 6-12 May 1970.

78 Kajak. Z. and Lawacz. W.: Comparison of tripton sedimentation in four small lakes. In: Golterman. H. L. (ed.): Interactions between Sediments and Freshwater. p. $72-75$ (1977). Proc. Int. Symp. Amsterdam. 6-10 September 1976.

79 Kajak, Z.. Lawacz. W.. Wiśniewski. R.J.. Rybak. J. I., and Dusoge, K.: Ecosystem of the Mikolajskie Lake. The fatc of organic matter of the profundal zone. Pol. Arch. Hydrobiol. 22, 89-99 (1975). 
80 Kamp Nielsen, L.: Seasonal variation in sediment-water exchange of nutrient ions in Lake Esrom. Verh. int. Verein. Limnol. 19, 1057-1065 (1975).

81 Kamp Nielsen, L.: Modelling the temporal variation in sedimentary phosphorus fractions. In: Golterman, H.L. (ed.): Interactions between Sediments and Freshwater, p. 277-285 (1977). Proc: Int. Synp. Amsterdam. 6-10 September 1976.

82 Kimmel. B.L., and Goldman, C.R.: Production, sedimentation, and accumulation of particulate carbon and nitrogen in a sheltered subalpine lake. In: Golterman, H. L. (ed.): Interactions between Sediments and Freshwater, p. 148-155 (1977). Proc. Int. Symp. Amsterdam, 6-10 September 1976.

83 Kimmel, B. L.. Axler, R.P., and Goldman, J.C.R.: A closing, replicate-sample, sediment trap. Limnol. Oceanogr. 22, 768-772 (1977).

84 Kirchner, W.B.: An evaluation of sediment trap methodology. Limnol. Oceanogr, 20, 657-660 (1975).

85 Klecrekoper. H.: A new apparatus for the study of sedimentation in lakes. Can. J. Zool. 30. 185$190(1952)$.

86 Kleerekoper. H.: The mineralization of plankton. J. Fish. Res. Bd Can. 10. 283-291 (1953).

87 Koidsumi, K., and Sakurai, Y.: Precipitating substances of Lake Suwa (Materials for the limnology of Lake Suwa. IV). Jap. J. Ecol. 18. 212-217 (1968) (in Japanese, engl, summary).

88 Lastein. E.: Recent sedimentation and resuspension of organic matter in eutrophic Lake Esrom. Denmark. Oikos 27. 44-49 (1976).

89 Lau. Y. L.: Laboratory study of cylindrical sedimentation traps. J. Fish. Res. Bd Can. 36 , $1288-1291(1979)$,

90 Lawacz. W: The characteristics of sinking materials and the formation of bottom deposits in a eutrophic lake. Mitt. int, Verein. Limnol, 17, 319-331 (1969).

91 Lund. J.W.G.. and Talling. J.F.: Botanical limnological methods with special reference to the algae. Bot, Rev. 23, 489-583 (1957) (see p.524 and 543).

92 Mason, D. L., Folger, D.W.. Haupt, R.S.. McGirr, R.R., and Hoyt. W. H.: Pollutant distribution from a new paper plant in southern Lake Champlain. Prepint (1977).

93 Matsuyama. M.: Organic substances in sediment and settling matter during spring in a meromictic lake Shigetsu. J. Oceanogr. Soc. Japan 29, 53-60 (1973).

94 Mesecar, R.: Benthic sampling system. Exposure 3. 5-7 (1975).

95 Mesecar. R., and Carey. A.G.. Jr.: In situ particle collector. Proc. Mar. Tech. Soc. and IEEE Ocean 75. p. $441-443$ (1975).

96 Miller. M.C.: The carbon cycle in the epilimnion of two Michigan lakes. Ph.D. thesis, Michigan Statc University, 1972.

97 Mitjagina. O.W.: Methodik zur Sammlung von suspendierten Stoffen in Stauseen sowie zur Analyse. Unpublished russian manuscript, 15 p. (1958), eited by Ohle [107].

98 Moore. H.B.: The muds of the Clyde Sea area. III. Chemical and Physical conditions; Rate and Nature of Sedimentation, and Fauna. J. Mar, Biol. Ass. U.K. 17, 325-358 (1931).

99 Mothes. G.: Sedimentationsvorgänge im Stechlinseegebiet. Acta hydrochim. hydrobiol. 5, 269--281 (1977).

100 Mueller. W. P.: The distribution of cladoceran remains in surficial sediments from three northern Indiana lakes. Invest. Indiana Lakes Streams 6. 1-63 (1964).

101 Neame, P.A.: Phosphorus flux across the sediment-water interface. In: Golterman, H.L. (ed.): Interactions between Sediments and Freshwater, p. 307-312 (1977). Proc. Int. Symp. Amsterdam. 6-10 September 1976.

102 Nichols, J., and Rowe. G. T: Infaunal macrobenthos off Cap Blanc. Spanish Sahara. J. Mar. Res. 35. 525-536 (1977).

103 Niklaus. M.: Geomorphologische und limnologische Untersuchungen am Oschinensee. Beitr. Geol. Schweiz, Hydrol. 14, 116 p. (1967).

104 Nishizawa, S., and lzeki. H.: Sediment trap applied in Bering Sea. Suspended Sediment Seminar Rec., Occan. Res. Insi., Tokyo 1975.

105 Odrich. E.: Untersuchung über die Sedimentation in Trinkwassertalsperren unterschiedlichen Trophiegrades. M.Sc, thesis, Math.-Nat. Fak., Univ. Leipzig. 1965.

106 Ohle. W.: Der Stofthaushalt der Seen als Grundlage einer allgemeinen Stoffwechseldynamik der Gewässer. Kieler Meeresforsch, 18, 107-120 (1962). 
107 Ohle, W.: Primärproduktion des Phytoplanktons und Bioaktivität holsteinischer Seen, Methoden und Ergebnisse, p. 24-43 (1965). Limnologie-Symposium, Helsinki 1964.

108 Okuda, T.: Metabolic circulation of phosphorus and nitrogen in Matsushima Bay (Japan) with special reference to exchange of these elements between sea water and sediments. Trabalhos Inst. Biol. mar. Oceanogr. Univ. Recife, Brazil 2, 7-154 (1960).

109 Olszewski, P.: Pierwsze limnologiczne badania jeziora rożnowskiego. Pr. Kom. Bad. Nauk. Rożn. 2 (1946).

110 Ott. B.: Community patterns on a submerged barrier reef at Barbados, West Indies. Int. Revue ges. Hydrobiol. 60, 719-736 (1975).

111 Otto, G., and Benndorf, J.: Über den Einfluss des physiologischen Zustandes sedimentierender Phytoplankter auf die Abbauvorgänge während der Sedimentation. Limnologica 8, 365-370 (1971).

112 Oviatt, A., and Nixon, S.: Sediment resuspension and deposition in Narragansett Bay. Est. Coast. Mar. Sci. 3, 201-217 (1975).

113 Parsons, T.R., Takahashi, M.. and Hargrave, B.T.: Biological Oceanographic Processes, 2nd ed.. p.229-235. Pergamon Press, Oxford 1977.

114 Patten, B.C., Young, D. K.., and Roberts, M.H., Jr.: Vertical distribution and sinking characteristics - of Seston in the lower York River, Virginia. Chesapeake Sci. 7, 20-29 (1966).

115 Peck. R.M.: Efficiency tests on the Tauber trap used as a pollen sampler in turbulent water flow. New Phytol. 71, 187-198 (1972).

116 Pennington. W.: The recent sediments of Windermere. Freshwat. Biol. 3, 363-382 (1973).

117 Pennington, W.: Seston and sediment formation in five Lake District lakes. J. Ecol. 62, 215-251 (1974).

118 Petersen. C.G. J., and Boysen Jensen. P.: Valuation of the sea. I. Animal life of the sea-bottom, its food and quantity. Rep. Dan. Biol. Stn 20, 3-76 (1911).

119 Prouse. N.J., and Hargrave, B.T.: Chlorophyll, carbon and nitrogen in suspended and sedimented particulate matter in St. Georges Bay. Nova Scotia. Fish. Mar. Ser. Tech. Rep. 721, 69 p. (1977).

120 Quasim, S.Z., and Sankaranarayanan, V.N.: Organic detritus of a tropical estuary. Mar. Biol. 15, 193-199 (1972).

121 Raymond, P.E., and Stetson. H.C.: A new factor in the transportation and distribution of marine sediments. Science 73, 105-106 (1931).

122 Ravera. O., and Viola. M.: Sedimentation-rate in a basin (Agno) of Lake Lugano. In: Golterman, H.L. (ed.): Interactions between Sediments and Freshwater, p. 174-178 (1977). Proc. Int. Symp. Amsterdam, 6-10 September 1976.

123 Reissinger, A.: Untersuchungen über den Niedersonthofener See im bayerischen Allgäu. Wiss. Veröff. dt. öst. Alpenver. 6 (1930). Innsbruck.

124 Reissinger, A.: Quantitative Untersuchungen über den Schlammabsatz im Alpsee, dem Niedersonthofener See und dem Starnberger See. Arch. Hydrobiol. 24, 535-542 (1932).

125 Revelle, R., and Shepard, F. P.: Sediments off the California Coast. Recent Marine Sed. Symposium, P.D. Trask (ed.). Am. Ass. Petrol. Geol, Bull., Tulsa, Oklahoma, p. 245-282 (1939) (Republ. 1955).

126 Reynolds, C.S.: Interrelations of photosynthetic behaviour and buoyancy regulation in a natural population of a blue-green alga. Freshwat. Biol. 5, 323-338 (1975).

127 Reynolds, C.S.: Sinking movements of phytoplankton indicated by a simple trapping method. I. A Fragilaria population. Br. Phycol. J. 11, 279-291 (1976).

128 Reynolds. C.S.: Sinking movements of phytoplankton indicated by a simple trapping method. II. Vertical activity ranges in a stratified lake. Br. Phycol. J. 1I, 293-303 (1976).

129 Reynolds. C.S.: Seston sedimentation: experiments with Lycopodium spores in a closed system. Freshwat. Biol. 9, 55-76 (1979).

130 Rhoads, D.C., and Young, D.K.: The influence of deposit-feeding organisms on sediment stability and community trophic structure. J. Mar. Res. 28, 150-178 (1970).

131 Rigler, F.H., MacCallum. M.E., and Roff, J.C.: Production of zooplankton in Char lake. J. Fish. Res. Bd Can. 31, 637..646 (1974).

132 Rossolimo, L.: Materialy k poznanju sedimentacii ozernych otlozenij (Material zur Kenntnis der Sedimentation der Seeablagerungen). Trudy Limnol. Sta. Kosine 21, 5-20 (1937) (Russ. with german summary). 
133 Rossolimo, L.: Some results on the clay sedimentation in the Moskva Canal System of the Ivankovski Reservoir (Moskva Dam). Works of the Federal Hydrobiol. Dept., vol.2, p.30-39 (1950) (Russ.).

134 Rowe, G.T., and Gardner, W.D.: Sedimentation rates in the slope water of the Northwest Atlantic Ocean measured directly with sediment traps. J. Mar. Res. 37, 581-600 (1979).

135 Rubinoff, R.W. (ed.): 1973 Environmental Monitoring and Baseline Data. Smithson. Inst. Envir. Sci. Progr., p. 140-141, 207-213 (1974).

136 Saijo, Y.: Chemical studies in lake metabolism (Japanese). J. Chem. Soc. Japan 77, 917-936 (1956).

137 Saijo, Y., Tsujimoto, A., Ichimura, S., and Takada, K.: Studies on lake deposits (2), Seasonal variation of deposits in Nakanuma, Ibaragi Prefecture (Japanese, engl. summary). Geograph. Rev. Japan 27, 69-76 (1954).

138 Schick, G.B., lsaacs, J.D., and Sessions, M.H.: Autonomous instrumentation in oceanographic research. In: Alt, F. (ed.): Marine Sciences Instrumentation, vol.4, p. 203-230 (1968).

139 Scott, W., and Miner, D. H.: Sedimentation in Winoma Lake and Tippecanoe Lake, Kosciusko County, Indiana, July 31, 1930 to July 30, 1935. Proc. Indiana Acad. Sci. 45, 275-286 (1936).

140 Seki, H., Skelding, J., and Parsons, T. R.: Observations on the decomposition of a marine sediment. Limnol. Oceanogr, 13, 440-447 (1968).

141 Serruya, C.: Rates of sedimentation and resuspension in Lake Kinneret. In: Golterman, H. L. (ed.): Interactions between Sediments and Freshwater, p.48-56 (1977). Proc. Int. Symp. Amsterdam, 6-10 September 1976.

142 Shepard. F. P.: Submarine Geology. Harper and Bros Publication, New York 1948. 1st ed.. 348 p. (see p. 30-35) and 2nd ed.. 1963 (see p. 131).

143 Smetacek, V., Bröckel, K. von, Zeitzschel, B., and Zenk, W.: Sedimentation of particulate matter during a phytoplankton spring bloom in relation to the hydrographical regime. Mar. Biol, 47, 211$226(1978)$.

144 Soutar, A., Kling, S. A., Crill, P.A.. Dufrin, E., and Bruland, K.W.: Monitoring the marine environment through sedimentation. Nature 266, 136-139 (1977).

145 Spencer, D.W., Brewer, P.G., Fleer, A., Honjo, S., Krishnaswami, S., and Nozaki, Y.: Chemical fluxes from a sediment trap experiment in the deep Sargasso Sea. J. Mar. Res. 36, 493-523 (1978).

146 Staresinic, N., Rowe, G. T., Shaughnessey, D., and Williams III, A. J.: Measurement of the vertical flux of particulate organic matter with a free-drifting sediment trap. Limnol. Oceanogr. 23, 559-563 (1978).

147 Steele, J.H., and Baird. I. E.: Sedimentation of organic matter in a Scottish sea loch. Mem. Ist. ital. Idrobiol., suppl. 29, 73-88 (1972).

148 Stepanek, M.: Sampler of sedimenting plankton. Sb. Vys. Sk. Chem. Technol. Praze; Oddlil Fak. Technol. Paliv. Vody. 7, 171-173 (1963).

149 Stephens, K., Sheldon, R.W., and Parsons, T.R.: Seasonal variations in the availability of food for benthos in a coastal environment. Ecology 48, 852-855 (1967).

150 Stiller, M.: Origin of sedimentation components in Lake Kinneret traced by their isotopic composition. In: Golterman, H.L. (ed.): Interactions between Sediments and Freshwater, p. 57-64 (1977). Proc. Int. Symp. Amsterdam, 6-10 September 1976.

151 Sugawara, K.: Chemical studies in lake metabolism. Bull. Chem. Soc. Japan 14. 375-451 (1939).

152 Syvitski, J.P.: Theory, utilization and reliability of suspended sediment collectors in lakes and oceans. 36 p. Inst. Oceanogr., University of British Columbia, Vancouver, unpublished manuscript (1978).

153 Taguchi, S., and Hargrave, B.T.: Loss rates of suspended material sedimented in a marine bay. J. Fish. Res. Bd Can. 35, 1614-1620 (1978).

154 Tauber, H.: Differential pollen dispersal and the interpretation of pollen diagrams. Danm. Geol. Unders. II, 89, 1-69 (1965).

155 Tauber, H.: Investigation of the mode of pollen transfer in forested areas. Rev. Palaeobot. Palynol. 3, 277-286 (1967).

156 Tauber, H.: A static non-overload pollen collector. New Phytol. 73, 359-369 (1974).

157 Thomas, E.A.: Beitrag zur Methodik der Produktionsforschung in Seen. Schweiz. Z. Hydrol. 12, 25-37 (1950).

158 Thomas, E.A.: Produktionsforschungen auf Grund der Sedimente im Pfäffikersee und Zürichsee. Verh. int. Verein. Limnol. 11, 409-421 (1951). 
159 Thomas, E.A.: Sedimentation in oligotrophen und eutrophen Seen als Ausdruck der Produktivität. Verh. int. Verein. Limnol. 12, 383-393 (1955).

160 Thomas, E.A.: Stofihaushalt und Sedimentation im oligotrophen Ägerisee und im eutrophen Pfäffiker- und Greifensee. Mem. Ist. ital. Idrobiol., suppl, 8, 357-465 (1955).

161 Thomas, E.A.: Sedimentation und Typeneinteilung des Türlersees. Verh. int. Verein. Limnol. 13 , 191-195 (1958).

162 Thomas, E.A.: Experimentelle Untersuchungen über die Schlammbildung in unberührten und kulturbeeinflussten Seen der Schweiz. Wass. Abwass. 1963, 1-19.

163 Toyoda, Y., Horie, S., and Saijo, Y.: Studies on sedimentation in Lake Biwa from the viewpoint of lake metabolism. Mitt. int. Verein. Limnol. 14, 243-255 (1968).

164 Trevallion, A.: An investigation of detritus in Southampton water. J. Mar. Biol. Ass. U.K. 47, 523 532 (1967).

165 Tsunogai, S., and Minagawa. M.: Sediment flux measurements by sediment trap and radiochemical estimation. Geochemistry of Funka Bay. Hokkaido, VI. Jap. Oceanogr. Soc. Ann. Meeting Abstr., p. 160 (1974).

166 Tsunogai, S., and Minagawa, M.: Th-234, Pb-210, and Po-210 in the surface and deep waters of the Pacific as tracers of particulate materials. EOS Transactions, Am. Geophys. Union 57, 255 (1976).

167 Tutin, W.: Preliminary observations on a year's cycle of sedimentation in Windermere, England. Mem. Ist. ital. Idrobiol., suppl. 8, 467-484 (1955).

168 Ulén, B.: Seston and sediment in Lake Norrviken. I. Seston composition and sedimentation. Schweiz. Z. Hydrol. 40, 262-286 (1978).

169 Von Bröckel, K.: Der Energiefluss im pelagischen Ökosystem vor Boknis Eck (westl. Ostsee). Diss. Univ. Kiel, 96 p. (1975).

170 Watanabe, Y., and Hayashi, H.: Investigation on the method for measuring the amount of freshly precipitating matter in lakes. Jap. J. Limnol. 32, 40.45 (1971).

171 Webster, T.J.M., Paranjape, M.A., and Mann, K.H.: Sedimentation of organic matter in St. Margaret's Bay. Nova Scotia. J. Fish. Res. Bd Can. 32, 1399-1407 (1975).

172 Weglenska, T., Hillbricht-Ilkowska, A., Kajak, Z., Bownik-Dylinska, L., Ejsmont-Karabin, J., Karabin, A., Leszczynski, L., and Prejs, K.: The effect of mineral fertilization on the structure and functioning of ecosystems of various trophic types of lakes. Part II: The effect of mineral fertilization on zooplankton, benthic fauna, and tripton sedimentation. Pol. Arch. Hydrobiol. 22, 233-250 (1975).

173 Wetzel, R.G., Rich, P.H., Miller, M.C., and Allen, H. L.: Metabolism of dissolved and particulate detrital carbon in a temperate hard-water lake. Mem. Ist. ital. Idrobiol, suppl. 29, 185-243 (1972).

174 White, W.S., and Wetzel. R.G.: A modified sedimentation trap. Limnol. Oceanogr. 18, 986-988 (1973).

175 White, W.S., and Wetzel, R.G.: Nitrogen, phosphorus, particulate and colloidal carbon content of sedimenting seston of a hard-water lake. Verh. int. Verein. Limnol. 19, 330-339 (1975).

176 Wiebe, P.H., Boyd. S.H., and Winget, C.: Particulate matter sinking to the deep-sea floor at $2000 \mathrm{~m}$ in the Tongue of the Ocean, Bahamas, with a description of a new sedimentation trap. J. Mar. Res. 34. 341-354 (1976).

177 Young, D.K.: Effects of infauna on the sediment and seston of a subtidal environment. Troisième Symposium Européen de Biologie Marine, suppl. 22, 557-571 (1971).

178 Young, D.K., and Rhoads, D.C.: Animal-sediment relations in Cape Cod Bay. Massachusetts. I. A Transect Study. Mar. Biol. 11, 242-254 (1971).

179 Zeitzschel, B.: Zur Sedimentation von Seston, eine produktionsbiologische Untersuchung von Sinkstoffen und Sedimenten der westlichen und mittleren Ostsee. Kieler Meeresforsch. 21 (H.I.), 55-80 (1965).

180 Zeitzschel, B., Diekmann, P., and Uhlmann, L.: A new multisample sediment trap. Mar. Biol. 45. 285-288 (1978).

REFERENCES II: Further literature quoted

181 Burns, N. M., and Pashley, A. E.: In situ measurements of the settling velocity profile of particulate organic carbon in Lake Ontario. J. Fish. Res. Bd Can. 31, 291-295 (1974). 
182 Batchelor, G.K.: An introduction to fluid mechanics, 593 p. Cambridge University Press, 1967.

183 Fowler, S.W., and Small, L.F.: Sinking rates of euphansiid fecal pellets. Limnol. Oceanogr. 17 , 293-296 (1972).

184 Golterman, H. L.: Studies on the cycle of elements in fresh water. Acta bot. neerl. 9, 1-58 (1960).

185 Golterman, H.L.: Mineralization of algae under sterile conditions or by bacterial breakdown. Verh. int. Verein. Limnol. 15, 544-548 (1964).

186 Hamblin, P.F.: Circulation and water movement in Lake Erie. Sci. Ser. No.7, Inland Waters Branch, Department of Energy, Mines and Resources, Ottawa, Canada, 1971.

187 Hutchinson, G.E.: A treatise on limnology. Vol.2: Introduction to Lake Biology and the Limnoplankton. Wiley \& Sons, New York 1967.

188 Hutchinson, G.E.: A treatise on limnology. Vol. 1, part 1: Geography and Physics of Lakes. Wiley \& Sons, New York 1975.

189 Jobson, H.E., and Sayre, W.W.: Vertical transfer in open channel flow. J. Hydraul. Div., Proc. Am. Soc. Civil Engin., p. 703-724 (1970).

190 Krause, H.R.: Biochemische Untersuchungen ubber den postmortalen Abbau von totem Plankton unter aeroben und anaeroben Bedingungen. Arch. Hydrobiol., suppl. 24 (3/4), 297-337 (1959).

191 Krause, H.R.: Abbau organischer Phosphorkomponenten aus totem Süsswasser-Zooplankton. Naturwissenschaften 47, 401-402 (1960).

192 Krause, H.R.: Zur Chemie und Biochemie der Zersetzung von Süsswasserorganismen unter besonderer Berücksichtigung des Abbaues der organischen Phosphorkomponenten. Verh. int. Verein.Limnol. 15, 549-561 (1964).

193 Kurtyka, J.C.: Precipitation measurements study. Report of investigation, No.20. Illinois State Water Survey, 1953.

194 Murray, St.P.: Settling velocities and vertical diffusion of particles in turbulent water. J. Geophys. Res. 75, 1647-1654 (1970).

195 Psenner, R.: Bakterien im Piburger See. Ph.D. thesis, University of Innsbruck, 192 p. (1976).

196 Scott, J.T., Meyer, G.E., Stewart, R., and Walther, E.G.: On the mechanism of Langmuir circulations and their role in epilimnion mixing. Limnol. Oceanogr. 14, 493-503 (1969).

197 Simons, T.J.: Continuous dynamical computations of water transports in Lake Erie for 1970. J. Fish. Res. Bd Can. 33, 371-384 (1976).

198 Smayda, T. J.: Some measurement of the sinking rate of fecal pellets. Limnol. Oceanogr. 14, 621625 (1969).

199 Smayda, T.J.: Normal and accelerated sinking of phytoplankton in the sea. Mar. Geol. 11, 105-122 (1971).

200 Smith, I. R.: Turbulence in lakes and rivers. Freshw. Biol. Ass. Sci. Publ., No. 29 (1975).

201 Titman, D., and Kilham, P.: Sinking in freshwater plankton: Some ecological implications of cell nutrient status and physical mixing processes. Limnol. Oceanogr. 21, 409-417 (1976).

Addresses of the authors: Dr. J. Bloesch, EAWAG, Abt. Limnologie, Uberlandstrasse 133, CH-8600 Dübendorf, Switzerland - Dr. N.M. Burns, CCIW, Aquatic Ecology Div., 867 Lakeshore Road, P.O. Box 5050, Burlington, Ontario, L7R 4A6 Canada. 